\title{
Hydnaceous fungi of the Hericiaceae, Auriscalpiaceae and Climacodontaceae in northwestern Europe
}

\author{
SARI KOSKI-KOTIRANTA and TUOMO NIEMELÄ
}

KOSKI-KOTIRANTA, S. \& NIEMELÄ, T. 1988: Hydnaceous fungi of the Hericiaceae, Auriscalpiaceae and Climacodontaceae in northwestern Europe. - Karstenia 27: 43-70.

Seven species of the families Hericiaceae Donk, Auriscalpiaceae Maas Geest. and Climacodontaceae Jülich are briefly described, and their distributions in northwestern Europe (Denmark, Finland, Norway and Sweden) are mapped. Hericium erinaceus (Bull.) Pers. is found only in Denmark and southem Sweden. Hericium coralloides (Scop.: Fr) Pers. is rather uncommon in the four countries, but extends from the Temperate zone to the Northern Boreal coast of North Norway. It seems to be absent from the most humid western areas. Its main hosts are species of Betula (ca. 65\%) and Populus (18\%), preferably trees growing in virgin forests. Creolophus cirrhatus (Pers.: Fr.) Karst. is common in the Southern Boreal zone and farther south; scattered records exist from the Middle Boreal zone and a few from the Northern Boreal zone. No records were found from the highly oceanic western coast of Norway. By far the commonest host genus of $C$. cirrhatus is Betula (69.5\%), followed by Populus (25\%). Dentipellis fragilis (Pers.: Fr.) Donk is a rare, predominantly Temperate to Hemiboreal species, favouring Fagus sylvatica $(50 \%)$ as its host. In Finland D. fragilis was found on Acer tataricum, Alnus sp., Prunus padus and Sorbus aucuparia; a new find is reported from the central part of the Middle Boreal zone, from Acer platanoides. Auriscalpium vulgare S.F. Gray has a relatively even distribution over the Temperate to Middle Boreal zones; only isolated records exist from the Northern Boreal zone. It is found equally frequently in the oceanic and continental parts of the area, growing on the cones of Pinus sylvestris (ca. 90\%) and Picea abies (10\%). Gloiodon strigosus (Swartz: Fr.) Karst. occurs sparsely throughout the Boreal zone, but is absent from the Temperate zone. It, too, is indifferent to the climatic oceanity, and it grows mainly on Populus tremula (ca. 46\%) and Alnus (23\%). Climacodon septentrionalis (Fr.) Karst. is a hemerophilous species, restricted to the Temperate and Southern Boreal zones. It is absent from oceanic western Norway and Denmark. Almost 20 hosts are listed, the commonest being Acer platanoides (ca. 49\%).

The vegetational zones in northwestern Europe are presented in a map which has been revised according to the most recent information, particularly as regards the Norwegian coast.

Sari Koski-Kotiranta \& Tuomo Niemelä, Department of Botany, University of Helsinki, Unioninkatu 44, SF-00170 Helsinki, Finland

Introduction

The study area

Materials and methods

Hericiaceae

Hericium erinaceus

Hericium coralloides

Creolophus cirrhatus

Dentipellis fragilis
44

44

45

45

46

48

52

55

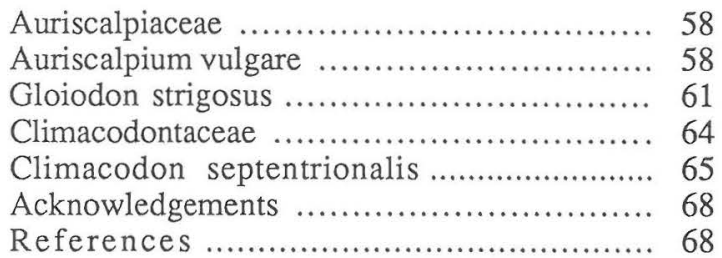




\section{Introduction}

The wood-inhabiting hydnaceous fungi have lately attracted the interest of many mycologists, and papers on the Nordic species have been published by, for example, Gulden and Stordal (1973), Strid (1982, 1983a, 1983b), Knudsen and Pedersen (1984), and Koski-Kotiranta and Niemelä (1983). Being written in the local languages, however, these fairly comprehensive reviews have received little attention outside their own area.

The taxonomical knowledge of the hydnaceous fungi was greatly improved by the works of Maas Geesteranus (1959, 1962, 1963, 1971, 1978). Other studies concerning lignicolous toothed fungi have been published by Harrison (1973a), Jahn (1965, 1969, 1979), Nikolaeva (1961), and Tortić \& Jelić (1977). The account of Domański (1975) gives a good general survey of the groups involved. James Ginns, in particular, has attempted to correlate the North American and European nomenclatural traditions for these fungi, also using mating tests in the laboratory.

Most of the above-mentioned authors followed the taxonomy of the Conspectus of the families of the Aphyllophorales by Donk (1964). Jülich (1981) attempted to amend the division of the families, but his treatment received rather harsh criticism, and later Jülich (1984) himself abandoned many essential parts of his classification. It seems that much more information is needed at the specific level before any elaborate new division into families can obtain universal acceptance. The taxonomical aspects are treated briefly in the present paper, and the classification of the fungi discussed has been selected from the - partly contradictory - divisions by Maas Geesteranus (1963), Donk (1964) and Jülich (1981).

In this study we deal with seven larger species of the group. Most of the resupinate hydnaceous fungi of North Europe have been described in the flora by Eriksson et al. (1973, 1975, 1976, 1978, 1981, 1984). Steccherinum oreophilum Linds. \& Gilb. was reported as new to the area by Niemelä and Saarenoksa (1985).

\section{The study area}

The research was carried out in northwestern Europe, comprising Denmark, Norway, Sweden and Finland. The treatment is mainly based on material from Norway, Sweden and Finland. Denmark has a more peripheral position in our synopsis, and the information from that country is mainly based on the literature, especially Knudsen and Pedersen (1984).

The southernmost parts of the area belong to the
Temperate vegetation zone (Ahti et al. 1968): the whole of Denmark, and the southern coastal areas of Norway and Sweden lie in this zone. These climatically most favourable areas are characterized by $\mathrm{Fa}$ gus sylvatica, which is an important deciduous host tree for many southern wood-rotting fungi. The rest of the Nordic countries belongs to the Boreal zone, except the high mountain Arctic (Oroarctic) outliers along the Scandes and in the North (Lapland).

The transitional southern part of the Boreal zone is the Hemiboreal subzone, which contains a mixture of many Temperate floral elements and the coniferous Taiga. The southern parts of Sweden and Norway are largely Hemiboreal, as is also the southwestern coastal strip of Finland. Quercus robur is native in the Hemiboreal (sub)zone, whose northern limit coincides fairly well with the distribution limit of this tree. (In the following, we refer to both the main zones and their subdivisions as 'zones'.)

The Southern Boreal zone covers the Southern Finnish Lake District, and extends up to the latitude of $64^{\circ} \mathrm{N}$ on the coast of the Gulf of Bothnia. In Sweden and Norway it stops farther south, narrowing down into a strip that can hardly be shown on maps on the western coast of Norway. This Southern Boreal zone is dominated by coniferous forests (mainly Picea abies), but birches and aspen are common, and many thermophilous hardwoods (Acer platanoides, Corylus avellana, Fraxinus excelsior, Ulmus glabra, etc.) are found in favourable sites.

Similarly, the Middle Boreal zone covers an extensive area in Central Finland, but only a coastal section in Central Sweden and an even narrower strip in western Norway. The Middle Boreal zone extends remarkably far north along the Norwegian coast, reflecting the warming influence of the Gulf Stream flowing north into the Norwegian Sea and the Arctic Ocean. Alnus glutinosa reaches the northern limit of this zone.

The Northern Boreal zone embraces northern Finland and the high areas of the Scandinavian Peninsula down to the southern tip of Norway. It is characterized by fairly few tree species, mountain birch (Betula pubescens ssp. tortuosa) at the upper limit, Norway spruce (Picea abies ssp. abies and ssp. obovata) in the lowlands, and Scots pine (Pinus sylvestris) on sandy soils. The timberline is formed by the mountain birch. Common trees over almost the whole area are Picea abies (introduced in Denmark, westernmost Norway and the southwestern coast of Sweden), Pinus sylvestris (introduced in Denmark), Alnus incana (introduced in Denmark and in southernmost Sweden), Betula pendula, B. pubescens, Populus tremula, Prunus padus and Sorbus aucuparia (e.g. Hultén 1971). 
The vegetation zones have been outlined in the map of Hericium erinaceus (Fig. 2). They follow mainly the delimitations of Ahti et al. (1968). For Norway a new map of the vegetation zones (Dahl et al. 1986) was followed, which is a remarkable elaboration of the zonation in that country, elucidating the area that Ahti et al. (1968) had to treat rather sketchily because of its fragmented outlines and extreme altitudinal variability. The summary presented here should give a fairly reliable and up-to-date picture of the vegetation zones in the whole area.

\section{Materials and methods}

The paper was prepared on the basis of the Cand. Phil. thesis of Sari Koski-Kotiranta (Koski 1983), but her study was expanded and complemented with material and additional species from the other Nordic countries. The first author did personal collecting only in Finland. The ecological information obtained from the herbarium annotations has been supplemented with the observations of the second author, $\mathrm{Mr}$ Heikki Kotiranta (Helsinki), Mr Reima Saarenoksa (Helsinki) and others.

The distribution maps are based on the material preserved in the public herbaria of $\mathrm{AAU}, \mathrm{BG}, \mathrm{C}$, GB, H, HFR, KUO, L, LD, TRH, TUR, OULU, UME and UPS (abbreviations according to Holmgren et al. 1981), and the private herbaria of Tuomo Niemelä and Prof. John Eriksson (Göteborg). Records from the literature and earlier mappings were included in the maps, being indicated with open circles. This inclusion of earlier data is justified by the fact that most of the species are well known and easy to identify.

Each column in the host list shows the frequency as a percentage calculated from the total number of specimens for which the host was indicated. For instance, in the first list (Hericium coralloides, p. $50), 64.3 \%$ of the collections originated from birches. Of these collections, $5.2 \%$ were from Betula pubescens and $1.4 \%$ from $B$. pendula. All the rest $(57.7 \%)$ almost surely came from the same host trees (other Betula species are very rarely cultivated in the area), but this was not indicated by the collectors. Similarly, Populus almost surely stands for P. tremu$l a$, Picea for $P$. abies and Pinus for $P$. sylvestris. In certain genera, however, especially Salix, very many species are possible. A plus (+) means one collection.

Every species was studied both macroscopically and microscopically, and the descriptions were constructed from these observations. The medium used most often for the microscopical studies was Melzer's reagent (IKI), but Cotton Blue (CB) and 5\% potassium hydroxide $(\mathrm{KOH})$ were also used. Sul- phobenzaldehyde (SBA) was used to stain the gloeocystidia and gloeoplerous hyphae. The chemical reactions are indicated according to the proposals of Niemelä (1985a, 1985b).

Sari Koski-Kotiranta prepared the distribution maps and the host lists, and wrote the species descriptions. She also made a draft for the sections Ecology and Distribution. Tuomo Niemelä revised the text, contributing mostly to the taxonomical, ecological and geographical discussions. The illustrations are by Tuomo Niemelä.

\section{Hericiaceae}

When describing the family, Donk (1964) took as its core the tribe Hericieae of Nikolaeva (1961), i.e. the genera Hericium Pers., Creolophus Karst. and Dentipellis Donk in the present sense. Donk considered the essential characters of the family to be the monomitic structure with predominantly thin-walled hyphae, the presence of gloeoplerous hyphae, and above all the amyloidity of the thick-walled, mostly ornamented spores. The other genera included by Donk (1964) were Clavicorona Doty, Laxitextum Lentz, Stecchericium Reid (Reid 1963; included in the Auriscalpiaceae by Jülich 1981), and with some reservations Gloeocystidiellum Donk. The delimitation of the family has been interpreted in various ways. Domański (1975) included Dentipratulum Dom., which resembles Mucronella Fr. in being composed of separate spines, not connected with a common subiculum. Jülich $(1981,1984)$ also included Mucronella, which Donk (1964) hesitated to accept because of the absence of gloeoplerous hyphae and variability in the spore amyloidity.

The concept of the family is far from settled, but new evidence is accumulating from studies on the spore wall structure. Electron microscopical investigations by Keller $(1976,1986)$ and Capellano and Keller (1978) revealed a very homogeneous spore wall structure in Creolophus, Dentipellis, Hericium, Clavicorona, Laxitextum and Gloeocystidiellum, and also in the Auriscalpiaceae (Stecchericium included) and the Letinellaceae (Kotlaba \& Pouzar 1972). The perispore, which is responsible for the amyloidity and ornamentation of the spores, is evenly thickened in Creolophus and some species of Gloeocystidiellum. Such spores have a smooth appearance (Tortić \& Jelić 1977), but otherwise their structure accords with that of the ornamented ones (Capellano \& Keller 1978). It now seems beyond doubt that these groups make up a natural entity. Whether the genera are included in one family or several (as by Jülich 1981) depends greatly on how much emphasis is laid on the morphological features. 

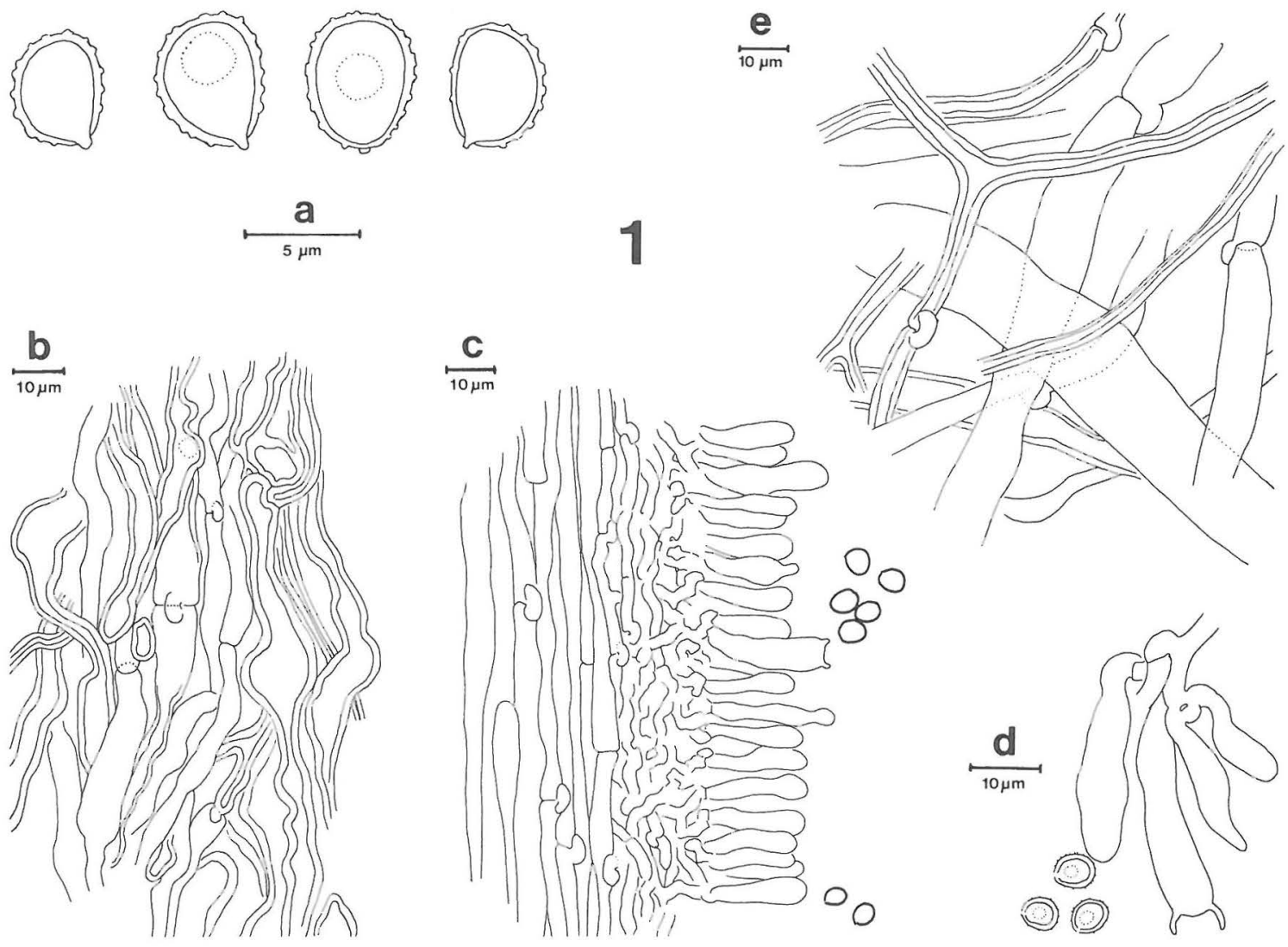

Fig. 1. Hericium erinaceus. a) spores, b) hyphae from the inner spine trama, c) superficial spine trama and hymenium, d) cells from the hymenium, e) contextual hyphae (U.S.A., Michigan, Oakland, 1961 Hintikka). Drawn in Mclzer's reagent.

\section{Hericium erinaceus}

Ilydnum erinaceus Bull., Herb. France pl. 34, 1780: Frics, Syst. Mycol. 1: 407, 1821. - Hericium erinaceus (Bull.: Fr.) Pcrs., Mycol. Europ. 2: 153, 1825. - For synonyms, sce Maas Geesteranus (1959). The specific name was used by Bulliard as a noun, which is therefore not inflected to agree with the gender of Hydnum. Many later authors have used incorrectly the adjectival form erinaceum (cf. Coker \& Beers 1951).

Fruit body annual, globose, compact or sometimes lobed, up to $20 \mathrm{~cm}$ in diam. Whole fruit body white, yellow or with a fleshy tint, when dry ochraceous or red-brown. Upper surface with short, irregular, sterile spines. Hymenophoral spines on underside $2-3(-5) \mathrm{cm}$ long, regularly crowded. Stipe short and lateral, or nonexistent. Smell and taste fruity.

Section: Context homogeneous, soft when fresh and tough when dry, yellowish white, with cavitites. Context changing into trama without separating zone. Trama yellowish white, homogeneous.
Hyphal system monomitic. Generative hyphae 3$15 \mu \mathrm{m}$ in diam, thick-walled, inflated, with amyloid walls and clamp connections, interwoven in the context and subparallel in the trama. Gloeoplerous hyphae $3-10 \mu \mathrm{m}$ in diam, filled with oily matter, often bent like gloeocystidia into the hymenium. Basidia 30-40 × 5-7 $\mu \mathrm{m}$, four-spored. Spores hyaline, minutely verrucose, 5-6 $\times 4-5 \mu \mathrm{m}$, fairly thickwalled, IKI blue, CB-.

More detailed descriptions and illustrations are to be found in Harrison (1973a), Jahn (1979), Strid (1983a) and Knudsen \& Pedersen (1984).

The morphology is usually adequate for identification, but dried specimens of $H$. erinaceus may sometimes be difficult to separate from a compact form of $H$. alpestre, especially since the spore size is the same. In the Nordic material no such problems were encountered, because $H$. alpestre is not found 


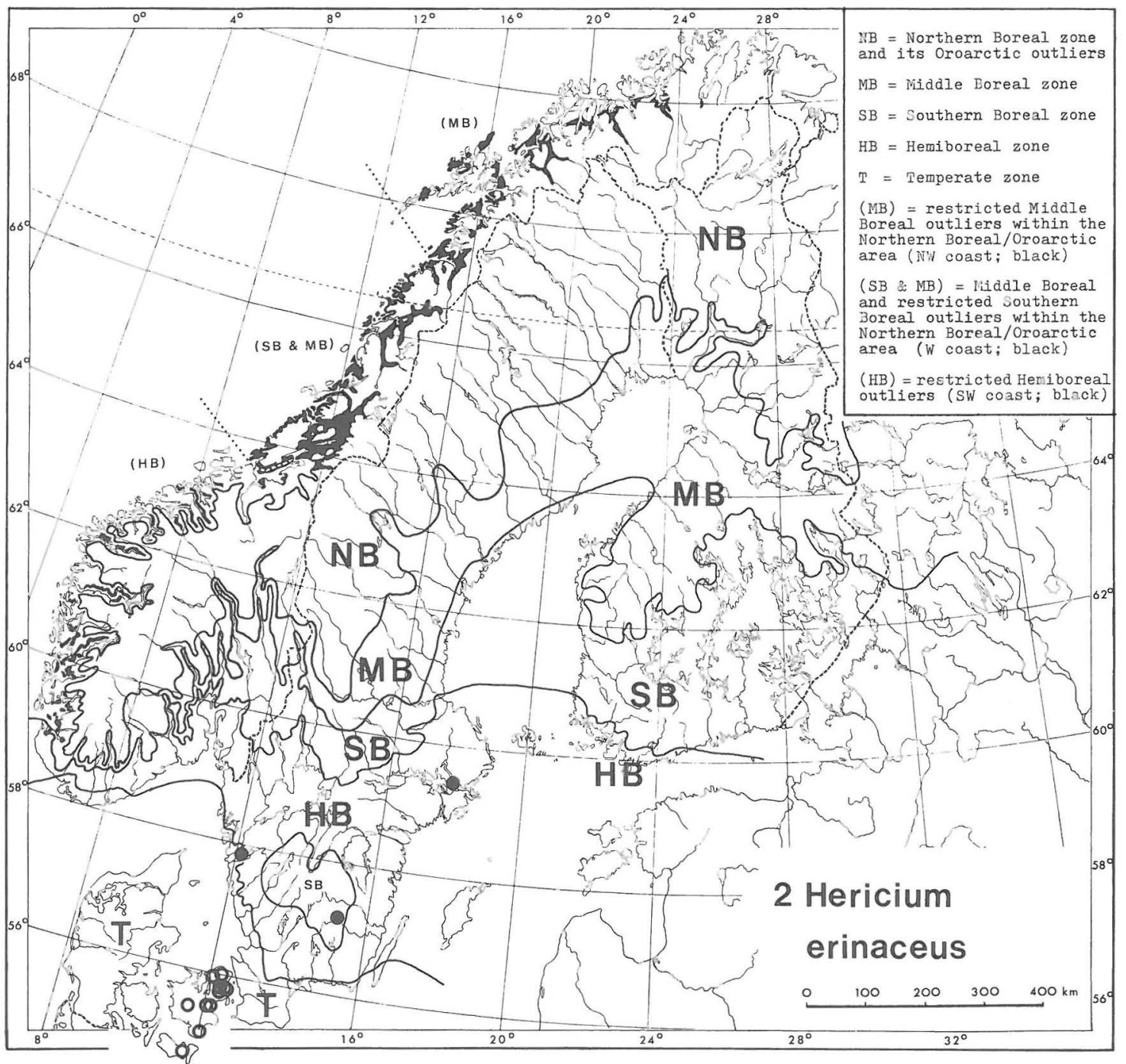

Fig. 2. The distribution of Hericium erinaceus in northwestern Europe, and the vegetation zones in the study area.

there (see under $H$. coralloides); the species is easily distinguished from $H$. coralloides.

\section{Distribution and ecology}

Hericium erinaceus is very rare in northern Europe, and has been found frequently only in Denmark. The few finds from southern Sweden show that the species is able to tolerate the conditions of the Hemiboreal zone, as well, and might possibly be found in the southwestern archipelago of Finland, too.

Due to its rarity (Sunhede 1977), H. erinaceus has been classified as endangered in Sweden (Ingelög et al. 1984), as also in Poland (Wojewoda \& Ławrynowicz 1986).

The species usually grows on Fagus sylvatica and Quercus robur, but also occurs on Betula, Juglans, Malus and Sorbus (Knudsen \& Pedersen 1984). In Central Europe further host trees are known. A characteristic site is a knothole or wound on a standing, living tree. In North America, the species causes serious heart-rot in oaks (Harrison 1973b). It has a similar pathology in Europe (Kreisel 1961), but its rarity diminishes its pathogenic importance. 
<smiles></smiles><smiles>C1=C=CC=CC=CC=1</smiles><smiles>C1=CC=CC=CC=C1</smiles>

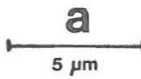
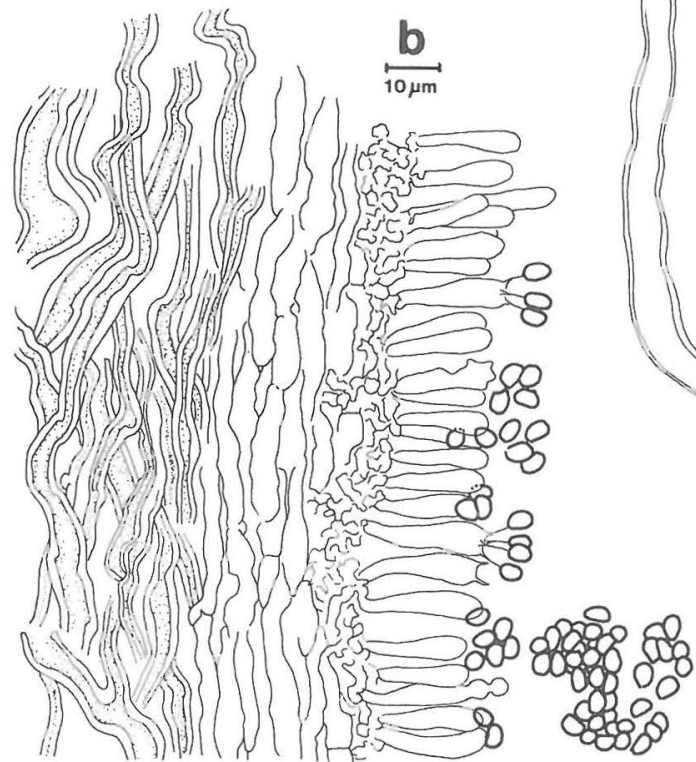
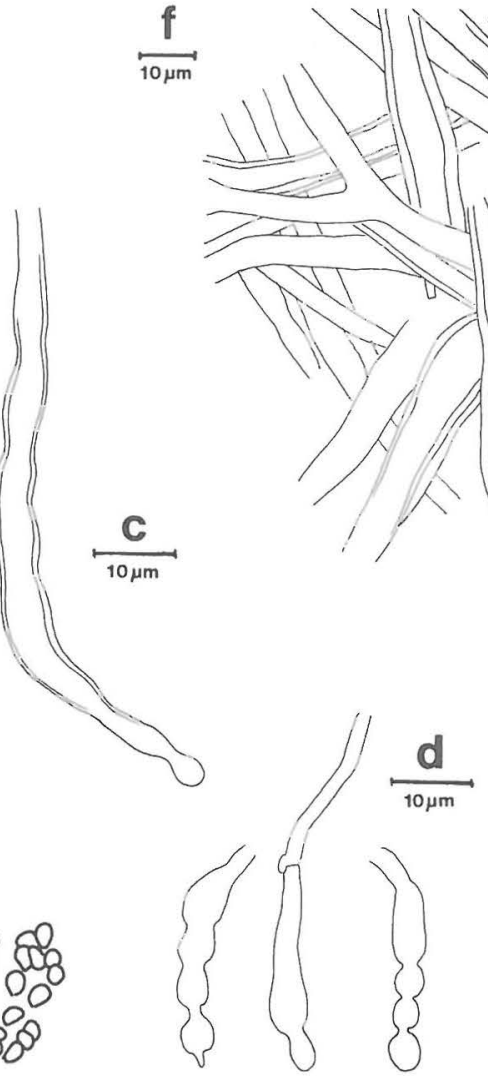
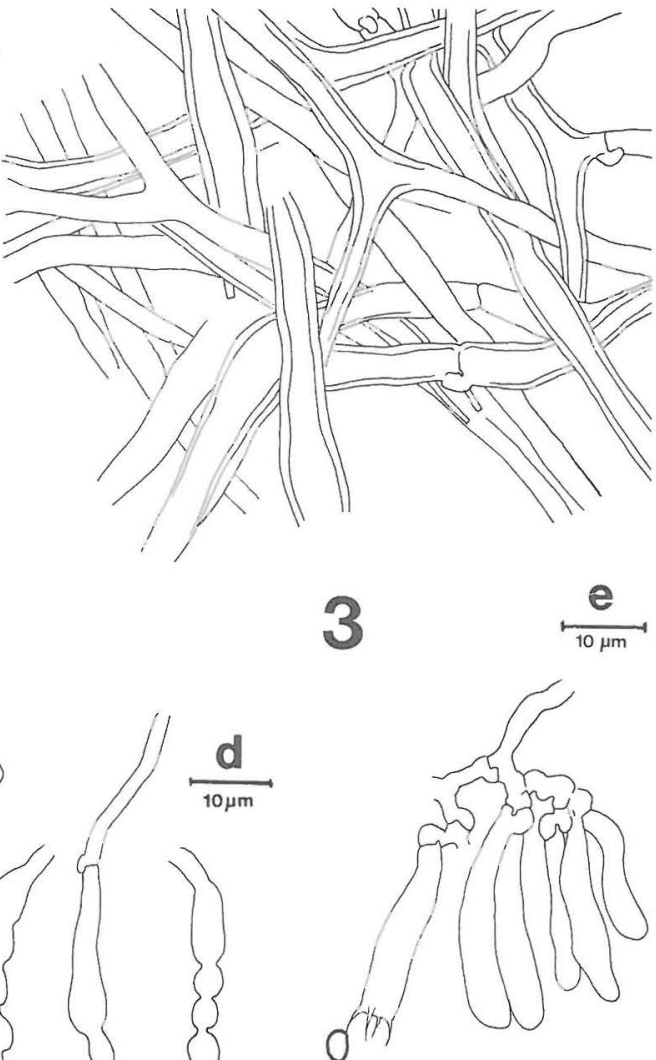

Fig. 3. Hericium coralloides. a) spores, b) spine in vertical section, c) gloeoplerous hypha from the spine apex, d) moniliform hyphae from mature hymenium, e) basidium and basidioles, f) contextual hyphae (Niemelä 1332). Abundant oil globules omitted from the sections; drawn in IKI.

H. erinaceus is found throughout Central Europe (Jülich 1984) down to the Mediterranean (Tortic \& Jelić 1977, Tellería 1980). It is widespread, though uncommon, in the U.S.A. (Coker \& Beers 1951, Harrison 1973a, Berry \& Lombard 1978, Ginns 1985), but does not seem to occur in Canada (Pomerleau 1980, Ginns 1985). Imazeki and Hongo (1972) report it from Japan. Nikolaeva (1961) mapped scattered occurrences throughout the Temperate zone in the Soviet Union. Maas Geesteranus (1971) listed the species from several countries of Southeast Asia. So $H$. erinaceus is evidently the most widely distributed species of the genus.

\section{Hericium coralloides}

Hydnum coralloides Scopoli, Flora carniolica 2(2): 472, 1772: Fries, Systema mycologicum 1: 408, 1821. - Hericium coralloides (Scop.: Fr.) Persoon, Neues Mag. Bot. 1: 109, 1794. - Neotype: Sweden, Småland, Femsjö, Fagus,
27.IX.1948 Lundell \& Hagström 5702, UPS (sel. Hallenberg 1983, discussed below). For synonyms, see Maas Geesteranus (1959).

Fruit body annual, repeatedly branched, coralloid, attached to the substrate with a common base or stipe; fleshy, white or cream when fresh, yellowish brown when old, up to $25-30 \mathrm{~cm}$ across though usually smaller, fresh weight up to $940 \mathrm{~g}$. Branching irregular; branches bearing spines at the ventral and lateral sides, dorsal surface glabrous. Spines up to $5 \mathrm{~mm}$ long, acute, cylindrical, not branched, evenly distributed under the branches like the teeth of a comb. Stipe short, white to cream, laterally attached to the wood.

Section: Context white, fleshy soft, homogeneous, continuing into spine trama without change or zonation. Surface slightly darker than the context.

Hyphal system monomitic. Generative hyphae 2-21 $\mu \mathrm{m}$ in diam, thin- or thick-walled, with clamp connections, inflated or not, interwoven in the con- 

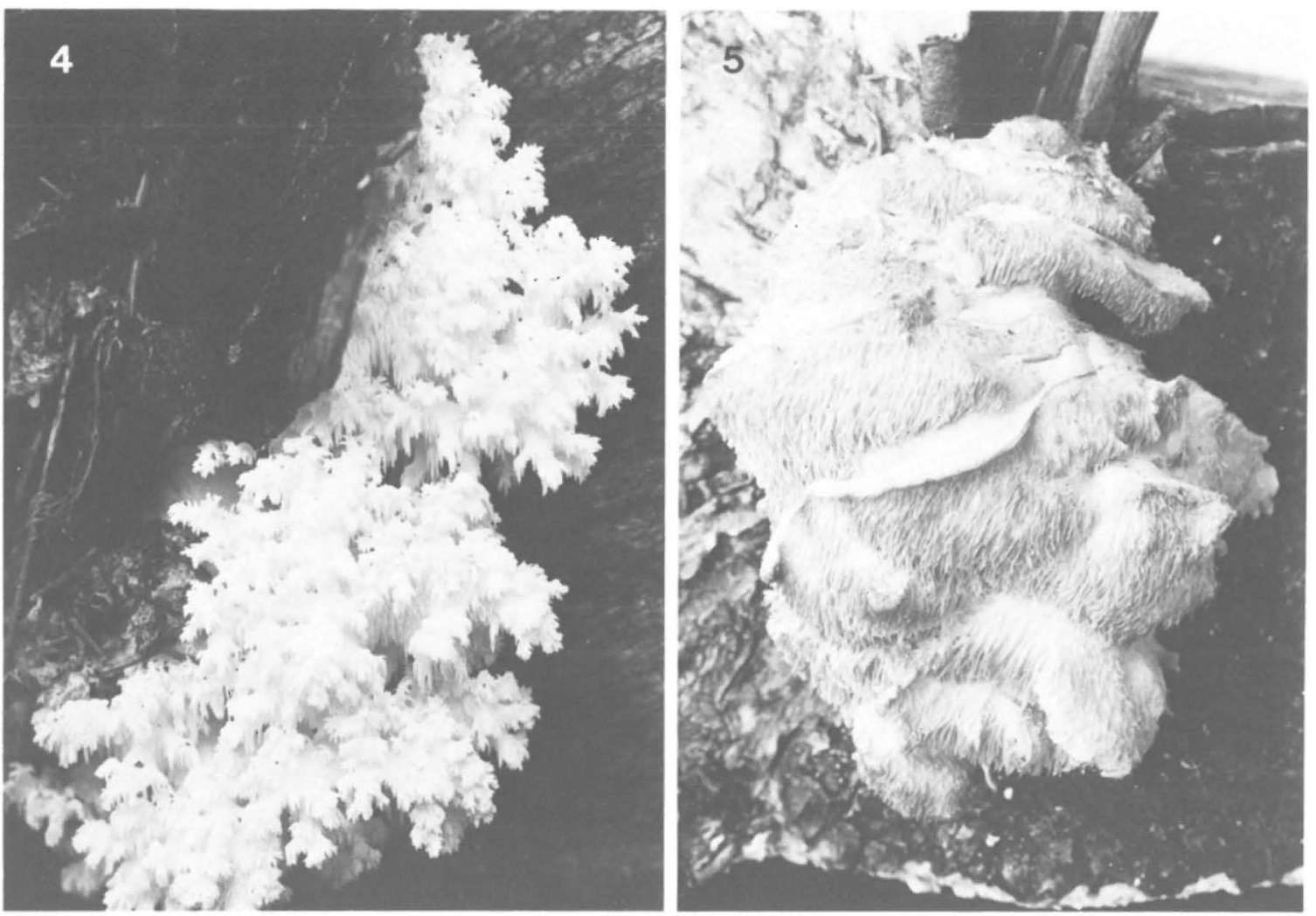

Figs. 4-5. Species of the Hericiaceae. - 4: Hericium coralloides (Niemelä 1579), x 0.7. - 5: Creolophus cirrhatus (1976 Kaila, T.N.), $x 0.9$.

text, subparallel in the trama, walls IKI blue. Gloeoplerous hyphae 4-7.6 $\mu \mathrm{m}$ in diam, filled with oily matter, which stains dark with SBA, unbranched, protruding into the hymenium as fusiform or moniliform gloeocystidia. Basidia slender, $15 \times 5 \mu \mathrm{m}$, fourspored. Spores subglobose, hyaline, fairly thickwalled, minutely verrucose, $3.5-5 \times 2.8-4.2 \mu \mathrm{m}$, IKI blue, $\mathrm{CB}$-.

\section{Ecology}

Hericium coralloides is a saprophyte of old deciduous trees, and causes a white-rot. A typical habitat is virgin forest where decaying trunks remain lying on the ground. In many cases the tree had been killed by Inonotus obliquus (Pers.: Fr.) Pil., and H. coralloides mostly emerged from below detached birch bark. The species is slightly hemerophobic.

$H$. coralloides has a rather wide host spectrum. In the Temperate zone the most frequent host is Fagus sylvatica. In northern and central parts of Fennoscandia, Betula species and Populus tremula serve most often as the hosts.

In Denmark the commonest host tree is Fagus sylvatica, and only one find from Betula was reported by Knudsen and Pedersen (1984). The Norwegian hosts were Betula sp., Populus tremula and Sorbus aucuparia, in this order. In Sweden, 21.8\% of the collections derived from Fagus sylvatica; these records came from the southern provinces of Skane, Blekinge and Småland. Betula was the host in $41.8 \%$ of the Swedish collections, being the commonest host throughout central and northern Sweden. Collections also exist from Acer platanoides, Alnus sp., Populus tremula, Ulmus sp., Salix sp. and Tilia cordata. In two Swedish collections, Abies was indicated as the host, but samples of the wood were lacking and it was impossible to confirm the determination; these collections also represented $H$. coralloides in the present sense. In Finland, $75.2 \%$ of the collections originated from species of Betula and $14.5 \%$ 
from Populus tremula. Some collections were also made from Acer platanoides, Alnus sp., Sorbus aucuparia and Tilia cordata. These records indicate that in northwestern Europe $H$. coralloides grows almost exclusively on hardwoods.

In Central Europe $H$. coralloides favours Fagus sylvatica, but has also been reported from the genera Betula, Carpinus, Corylus, Fraxinus, Juglans, Morus, Pyrus, Quercus and Ulmus (Kreisel 1961, 1987, Tortic \& Jelić 1977, Jahn 1979).

Host list for Norway, Sweden and Finland:

\begin{tabular}{|c|c|c|c|c|}
\hline & $\begin{array}{c}\text { All I } \\
\text { countries }\end{array}$ & Norway & weden & Finland \\
\hline $\begin{array}{l}\text { Betula } \\
\text { - pubescens } 5.2 \\
\text { - pendula } 1.4\end{array}$ & 64.3 & 30.0 & 41.8 & 75.2 \\
\hline $\begin{array}{l}\text { Populus } \\
\text { - tremula } 17.1 \\
\text { - balsamifera+ } \\
\text { Fagus sylvatica }\end{array}$ & 18.1 & 40.0 & 23.6 & 14.5 \\
\hline $\begin{array}{l}\text { Alnus } \\
\text { - incana } 1.9 \\
\text { - glutinosa } 0.9\end{array}$ & 4.3 & - & 3.6 & 4.1 \\
\hline Acer platanoides & 2.8 & - & 3.6 & 2.7 \\
\hline Sorbus aucuparia & 2.8 & 30.0 & - & 2.1 \\
\hline Ulmus & 1.0 & - & 3.6 & - \\
\hline Salix & + & - & + & - \\
\hline $\begin{array}{l}\text { Tilia cordata } \\
\text { Host not indicated }\end{array}$ & $\begin{array}{l}+ \\
93\end{array}$ & - & - & + \\
\hline Specimens examined & 303 & 17 & 95 & 191 \\
\hline
\end{tabular}

\section{Distribution}

In Denmark, Knudsen and Pedersen (1984) regard Hericium coralloides as the commonest species of the family, but even so its distribution is restricted to fairly remote woods that are not cared for very well. It seems to avoid the most oceanic western areas, but it should be noted that the western half of the country is less forested than the eastern part. Scattered finds have been made over Norway and Sweden, but the species seems to be absent from the most humid southwest of Norway. The northernmost find in Fennoscandia is from Norway, Finnmark: Alta. In Finland $H$. coralloides has been collected fairly evenly in the southern and central parts, but is rarer in the Northern Boreal zone north of the Arctic Circle. Nowhere is it common, the occurrences being scattered even in its best sites. It is found regularly only in old virgin forests, where suitable hosts and biotopes exist.

H. coralloides occurs throughout Central Europe (Jülich 1984, Kreisel 1987) to the Mediterranean countries (Tellería 1980, Tortić \& Jelić 1977, Bernicchia \& Caroti 1983) and Caucasia (Klán \& Kotilová-Kubicková 1982).

According to Plank (1978), the species has a holarctic general distribution. Confusion with related species (see Taxonomy and nomenclature) makes it difficult to know the total distribution. However, Ginns (1985) gives reliable reports of $H$. coralloides from Canada and the U.S.A., the distribution extending from the eastern coast of North America to British Columbia and Alaska in the west. This is the most commonly collected North American Hericium (Ginns 1985). According to Nikolaeva (1961), the European distribution continues via South Siberia to the Soviet Far East and Kamchatka; Gordienko (1979) also reported it from the easternmost U.S.S.R. According to Imazeki and Hongo (1972), it occurs in Japan, and Maas Geesteranus (1971) gave further reports from Pakistan, India, China and Indonesia. The collections from these exotic areas probably deserve to be revised in the light of the new criteria.

\section{Taxonomy and nomenclature}

The taxonomy of Hericium coralloides has long been unsettled, but the studies of Hallenberg (1983) and Ginns $(1984,1985)$ seem to have put its identity and nomenclature on a sound basis. The name was earlier used mostly in a collective sense, including both the present species growing on hardwoods, and another which grows mainly on Abies in the montane forests of Central Europe. Maas Geesteranus $(1959,1971)$ described the differences between the two, and referred the present species to Hericium clathroides (Pallas: Fr.) Pers., retaining the name $H$. coralloides for the montane species on Abies. This practice was followed for a long time; at times the name $H$. clathroides was replaced with $H$. ramosum (Bull.) Let. (e.g. Harrison 1973a, Domański 1975, Tortić \& Jelić 1977, Lindsey \& Gilbertson 1978) or H. laciniatum (Leers) Banker (Coker \& Beers 1951).

The correct interpretation of the name coralloides should be sought in the protologue by Scopoli (1772), whose name was sanctioned by Fries (1821). In the typification Scopoli's concept should be followed, but the material cited in the sanctioning author's description can also be used (cf. Korf 1982).

In the absence of any original herbarium material, Hallenberg (1983) analysed the description of Scopo- 


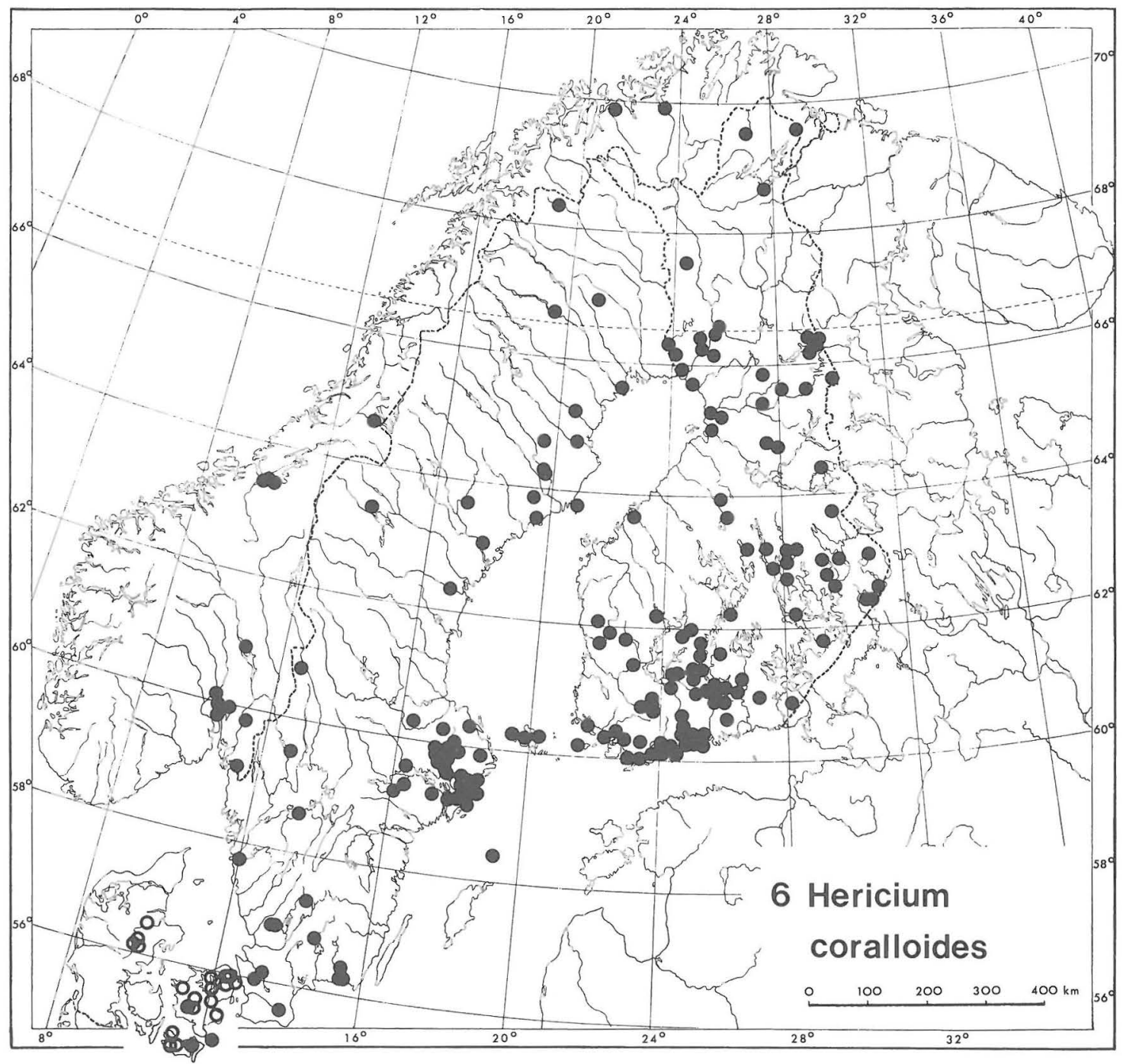

Fig. 6. The distribution of Hericium coralloides in northwestern Europe.

li (1772) and the references to earlier texts and illustrations in it. No definite detail was found pointing clearly to one species or another. Although long, Scopoli's description is too general to allow the separation of the related species. Scopoli's area of research, 'Carniola', is now known as Idrija and lies in western Slovenia, Yugoslavia (Stafleu \& Cowan 1985). Tortić and Jelić (1977) list eight localities in Yugoslavia for $H$. alpestre (i.e. the Abies-preferring species). For the present species they list 10 localities and also give eight identifiable literature records. So Hallenberg's (1983) conclusion that Scopoli's coral- loides was the species of Fagus and other hardwoods can be neither proved no disproved. Unfortunately, in the particular area around Idrija both beech and fir forest are found (Tortić \& Jelić 1977), and so either of the species may have grown there.

The situation in Scopoli's 'Carniola' leaves the selection of the type fairly free. Hallenberg (1983) cut the Gordian knot by following the concept of Fries (1821), which can be reliably traced, and selected a recent neotype from Femsjö, Sweden. A specimen from the collecting area of Scopoli would have been preferable, but Hallenberg's solution does 
not contravene the Code, and must be followed. Maas Geesteranus (1971) indicated 'Krain' (i.e. Idrija) as the type locality of $H$. coralloides, but did not mention any specimen, and so he did not make an effective typification. The present typification can be altered only by the finding of an original collection that can serve as a holotype or lectotype, and this is not probable: according to Stafleu and Cowan (1985) Scopoli's specimens are preserved in LINN, C, M, UPS, B and MPU, possibly also in PAV and PHAL, but our inquiries did not bring to light any original specimen of this taxon.

Less confusion has attached to the name of the Abies-preferring species growing in the mountains of Central and South Europe. The description of Hericium alpestre Pers. (Persoon 1825) is clear, and two (albeit poor) original collections exist in $\mathrm{L}$ (Hallenberg 1983). Though at first sight similar to $H$. coralloides, $H$. alpestre differs in having the spines only as terminal tufts on the branches or on short lateral processes. Besides, it has bigger spores (4.4$5.4 \times 5.6-6.3 \mu \mathrm{m}$ according to Maas Geesteranus 1971) and grows almost solely on Abies, in Europe mostly A. alba (Nuss 1973). It has not been found in the Nordic countries. Kreisel (1987) used the name $H$. flagellum (Scop.) Pers. for this taxon, which may be the oldest name according to the new Code (the species has no sanctioned name).

Four Hericium species have been reported from North America (Harrison 1973a, Lincoff 1981). Their proper names were decided only recently, when Ginns $(1984,1985)$ made comparisons and crosses with the European material. Hericium erinaceus has been correctly understood. Our $H$. coralloides has the name $H$. ramosum in Harrison (1973a), Lindsey and Gilbertson (1978), Lincoff (1981) and Pomerleau (1980), and $H$. laciniatum in Coker and Beers (1951). The ' $H$. coralloides' of all these authors is an independent species, which Ginns (1984) described as $H$. americanum Ginns. $H$. americanum resembles $H$. alpestre in having spines arranged as tufts, but has slightly bigger spores and grows on broad-leaved trees. In the Pacific Northwest there is another American species, $H$. abietis (Weir ex Hubert) Harrison, which resembles the European $H$. alpestre in having spines arranged as tufts, and in growing on conifers. Its close resemblance to its European counterpart casts doubts on its independence, but Ginns (1985) showed that the cultures of the two taxa do not mate. $H$. alpestre thus seems to be absent from North America.

\section{Creolophus cirrhatus}

Hydnum cirrhatum Pers., Syn. Meth. Fung.: 558, 1801: Fries,
Syst. Mycol. 1: 411, 1821. - Creolophus cirrhatus (Pers.: Fr.) Karst., Medd. Soc. Fauna Flora Fennica 5: 42, 1879. Typus: not designated, no original collection found in herb. Persoon (L).

Fruit body annual, bracket-like or lumpy and variable in shape, consisting of a single or several (up to 15) partly confluent caps, which are compact, initially white to cream, but develop a reddish tint as they age or dry, soft and spongiose when fresh, hard when dry. Taste and smell mild. Pileus $5-10 \mathrm{~cm}$ wide, broad at the base, semicircular, upper surface rough, covered with sterile, stiff, scattered hairs. Margin often inrolled. Spines up to $15 \mathrm{~mm}$ long, cylindrical, acute, creamy white when fresh, turning reddish when dry.

Section: Context up to $5 \mathrm{~mm}$ thick, homogeneous, tough, ochraceous-white. Trama of the spines homogeneous, though, pale ochraceous. No zonation between context and trama.

Hyphal system monomitic. Generative hyphae 2$13 \mu \mathrm{m}$ in diam, infrequently septate with clamp connections, branched, thick- or thin-walled, inflated, IKI-. Gloeoplerous hyphae in the trama 3-8 $\mu \mathrm{m}$ in diam, filled with oily matter, protruding to the hymenium as gloeocystidia. Basidia slender, $25 \times 4 \mu \mathrm{m}$, four-spored, with basal clamp. Spores ellipsoid or subglobose, hyaline, smooth, 3.5-4.5 × 2.6$3.5 \mu \mathrm{m}$, IKI blue, $\mathrm{CB}$ - .

Externally, C. cirrhatus can be confused with small specimens of Climacodon septentrionalis, but the former has a soft, spongy texture, while the latter has a tough fibrous context. In the microscope $C$. cirrhatus is identifiable by its amyloid spores and gloeocystidia, while $C$. septentrionalis has nonamyloid spores and thick-walled, oil-free cystidia. The genus Creolophus is separated from Hericium by the smooth spores and nonamyloid contextual hyphae. The ontogeny of the growing basidiocarp and the microscopical changes that it undergoes during maturation have been described by Maas Geesteranus (1962).

\section{Ecology}

The species is predominantly saprophytic, but it sometimes seems to grow as a parasite of living trees, emerging from fairly large and fresh wounds. $C$. cirrhatus appears within a few years after the tree has fallen or has been felled (also observed by Jahn 1965,1979 ), and is thus a pioneer organism causing decay in hard, abruptly deceased wood. The frequent occurrence in well-illuminated, fairly open sites also emphasizes the pioneer character of the fungus. In this respect it differs distinctly from Hericium coral- 


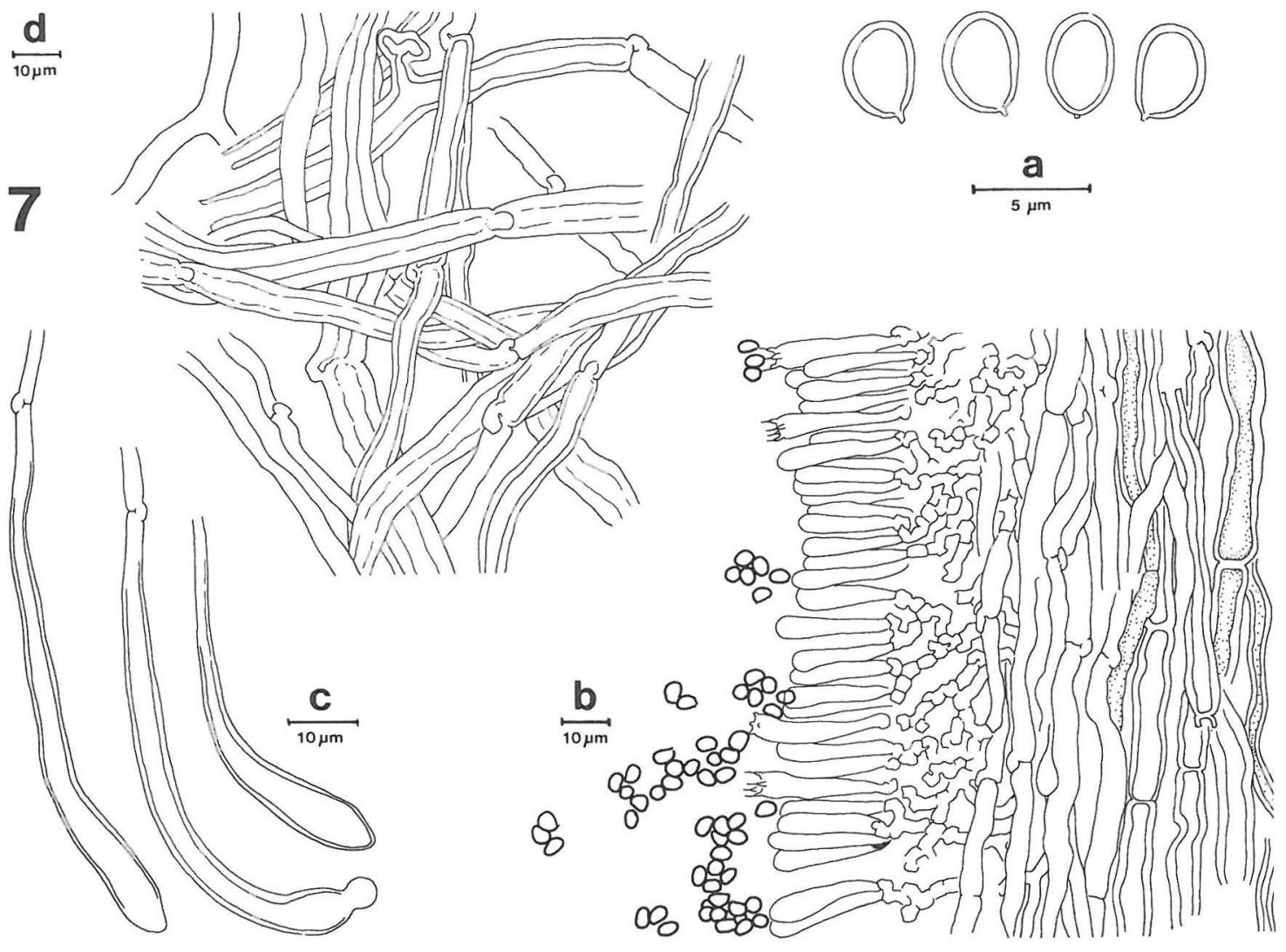

Fig. 7. Creolophus cirrhatus. a) spores, b) spine in vertical section, c) gloeoplerous hyphae close to the spine apex, d) contextual hyphae (Niemelä 2151 \& Kotiranta). Drawn in IKI; the hyphal walls appear much thinner in CB.

loides, which is found on soft substrates, already rotted by other fungi.

Fruit bodies emerge mostly from exposed wood, for instance from the broken surface of a blowndown tree. The species causes a hard white-rot.

C. cirrhatus is fairly clearly hemerophilous, as is evident from the distribution map. Nevertheless, in the Nordic countries it does not belong to the extreme group which is restricted to urban and other manmade habitats, and so it is not comparable to Climacodon septentrionalis and those polypores which were termed 'centric' by Erkkilä and Niemelä (1986).

In Denmark (Kundsen \& Pedersen 1984), C. cirrhatus is found on Fagus sylvatica only. In the other Nordic countries the preference of birch is very strong, as can be seen from the list below. About one quarter of the finds originate from aspen (in practice Populus tremula), while the other hosts are rather infrequent. Gulden and Stordal (1973) also mention Sambucus as a host in Norway.
In Central and South Europe and the European U.S.S.R., the most frequent hosts are Fagus sylvatica, Betula species and Carpinus betulus, and the fungus has also been found on species of Quercus and Prunus (Nikolaeva 1961, Jahn 1965, Tortić \& Jelić 1977, Jülich 1984). Kreisel (1987) listed nine host tree genera in the German Democratic Republic.

Host list for Norway, Sweden and Finland:

All Norway Sweden Finland countries

$\begin{array}{lllll}\begin{array}{l}\text { Betula } \\ \text { - pubescens 4.1 }\end{array} & 69.5 & 73.7 & 61.3 & 73.2 \\ \begin{array}{l}\text { Populus } \\ \text { - tremula 10.5 }\end{array} & 24.9 & 15.8 & 29.0 & 24.1 \\ \text { - alba }+ & & & & \\ & & & & \end{array}$




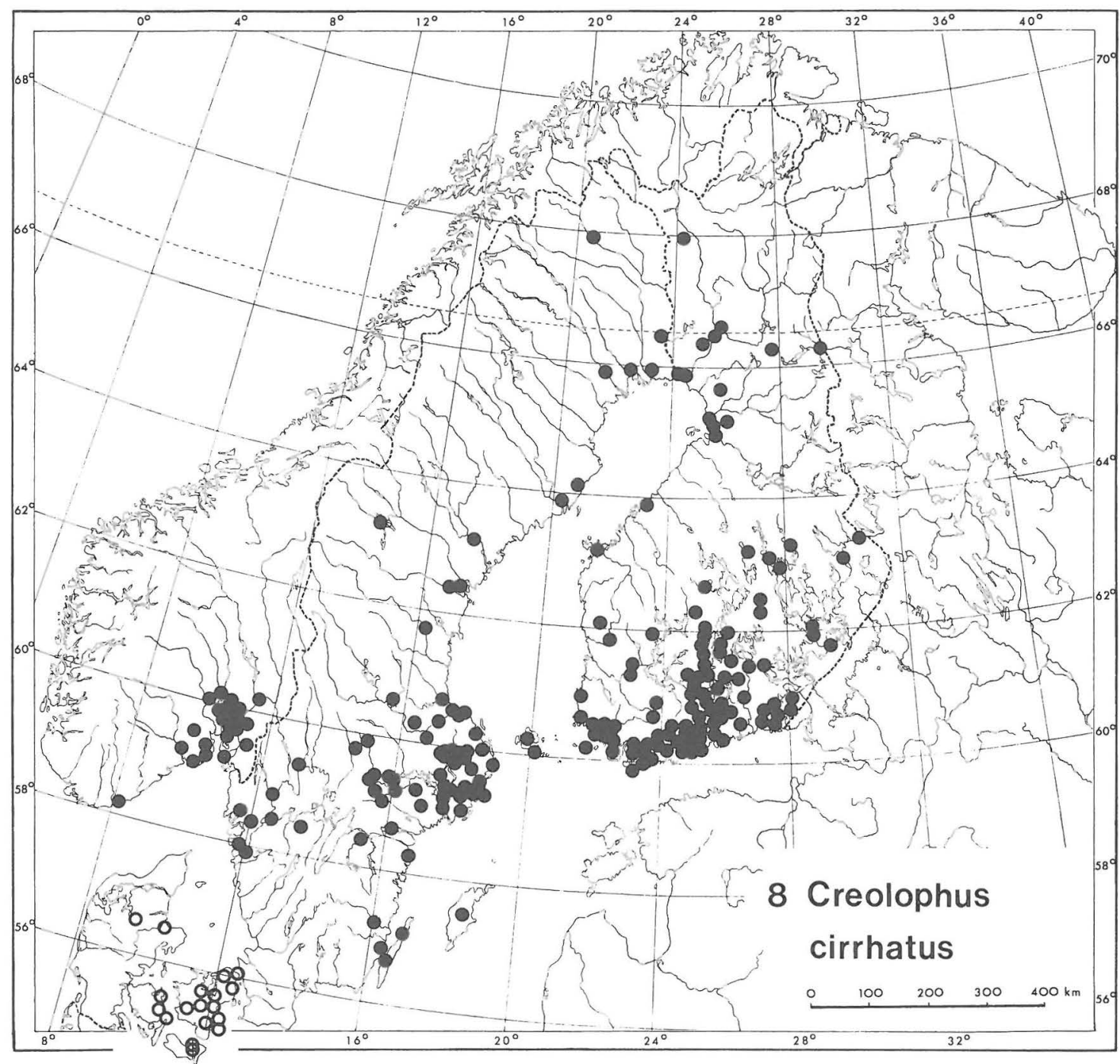

Fig. 8. The distribution of Creolophus cirrhatus in northwestern Europe.

Salix

- caprea 1.0

-fragilis +

Sorbus aucuparia

Acer platanoides

Aesculus hippoc.

Alnus incana

Quercus robur

Ulmus

Host not indicated

Specimens examined
2.0

10.5

1.0
+
+
+
+
+
123
320
$0.5++$

$\begin{array}{lll}- & + & + \\ - & + & - \\ - & + & - \\ - & - & + \\ - & + & - \\ - & + & -\end{array}$

$\begin{array}{lll}39 & 113 & 168\end{array}$

\section{Distribution}

The distribution of Creolophus cirrhatus in the Nordic countries shows a southern tendency, though it has been found up to the latitude of $68^{\circ} \mathrm{N}$ in both Finland and Sweden.

Most of the Danish finds have been made in the eastern half of the country. In Norway all the collections except one originate from the surroundings of the capital, Oslo. The distribution is fairly southern in Sweden, too, and the finds are concentrated in the biogeographic provinces of Uppland and Stock- 
holm, and in the surroundings of Göteborg. However, the species is surprisingly rare in the South Swedish provinces of Småland, Skåne and Blekinge, showing a clear gap in the distribution. The reason for this irregularity is unknown to us, though it may be due merely to uneven collecting. In Sweden the species is common in the Hemiboreal zone, and scattered in the Southern and Middle Boreal zones; only one find was made in the Northern Boreal zone, in Swedish Lapland.

In Finland $C$. cirrhatus is fairly common in the Hemiboreal and Southern Boreal zones, while its abundance drops sharply in the Middle Boreal zone. There is a general tendency for the species to become more abundant towards the east.

Climatically, $C$. cirrhatus has a distinct continental preference. There are no finds from the oceanic western coast of Norway, and the species is absent from westernmost Denmark. The Swedish and Finnish distributions also suggest concentration in the more continental eastern halves. On the other hand, the patterns in Norway, Sweden and Finland coincide with the most densely inhabited areas of the countries and are partly explained by the more intensive collecting in those parts, but the map also reveals a hemerophilous tendency, i.e., preference of environments slightly affected by man. Birch, the main host in the area, is common up to the northern limit.

C. cirrhatus seems to avoid westernmost Europe (Jülich 1984). It has been reported throughout Central Europe (Kreisel 1961, 1987, Jahn 1965, Jülich 1984, Breitenbach \& Kränzlin 1986), extending south to Yugoslavia (Tortić \& Jelić 1977), the Carpathians (Zerova et al. 1972), and Armenia south of the Caucasus (Melik-Hacatryan \& Martirosyan 1971). In the Mediterranean area, however, it is rare and found mainly in the mountains (Marchand 1976). Tellería (1980) did not report it in Spain.

In the east, the species extends to at least Kazakhstan (Svarcman 1964) and the Yenisei River in Central Siberia (Nikolaeva 1961), where it possibly has its easternmost occurrences. It was not reported by Maas Geesteranus (1971) from the eastern Old World, or by Lyubarskij and Vasilyeva (1975) from the Soviet Far East, by Rattan (1977) from the Himalayas, or by Imazeki and Hongo $(1971,1972)$ from Japan.

Surprisingly, Harrison (1984) reported two collections of $C$. cirrhatus from the southwestern U.S.A. (Colorado and New Mexico), which he claims to be the first finds in North America. We have not studied the specimens from that suspiciously isolated occurrence.

\section{A note on the taxonomy}

Donk (1962) reestablished the status of the genus Creolophus, and his proposal for separating it from Hericium has mostly been followed. Donk's criteria for the separation of the two genera were rather vague, however. In his key (Donk 1962: 231), the morphological separation does not always work correctly, and $H$. erinaceus, for instance, would key out as Creolophus. The only clear difference is the amyloidity of the context in Hericium and the nonamyloidity in Creolophus, which has been regarded as an inadequate diagnostic character in countless other genera of the Aphyllophorales.

Maas Geesteranus (1963) pointed out another difference. In Hericium, most of the spinal hyphae are thick-walled, while they are all thin-walled in Creolophus.

The scanning and transmission electron microscopy carried out by Tortić and Jelić (1977), Capellano and Keller (1978) and Keller (1986) has substantiated the proposed generic division by revealing differences in the spore walls, viz. smooth in Creolophus and ornamented in Hericium.

These microscopical differences between the two genera are small, but perhaps enough to distinguish them. An analogous situation exists in the Perenniporiales, where the polypore genera Haploporus and Pachykytospora (which could well be united) have ornamented spores and Perenniporia (including Truncospora) has smooth; other clear differences are not easily found.

\section{Dentipellis fragilis}

Hydnum fragile Persoon, Syn. Method. Fungorum 1: 561, 1801: Fries, Syst. Mycol. 1: 417, 1821. - Dentipellis fragilis (Pers.: Fr.) Donk, Persoonia 2: 233, 1962. - Neotype: 'Hydnum fragile (msit Ludwig)', Herb. Persoon (L 910.262-508, selected here; indicated as 'type' by Donk in herb. 1929). See note in Donk (1962: 233); further synonyms have been listed and discussed in that paper.

Fruit body annual, resupinate, creamy white, thin, soft when fresh and fragile when dry. Margin undulating and following the depressions of the bark substrate, broadly sterile, loosely attached and often projecting from the substrate. Spines up to $10 \mathrm{~mm}$ long, cylindrical, acute, white when fresh, fragile and pale ochraceous when dry. No specific taste or smell.

Section: Subiculum up to $1.5 \mathrm{~mm}$ thick, creamy white, homogeneous, soft and cottony when fresh, fragile when dry, changing into trama without demarcation. Trama of the spines homogeneous, cream, soft, fragile.

Hyphal system monomitic. Generative hyphae 


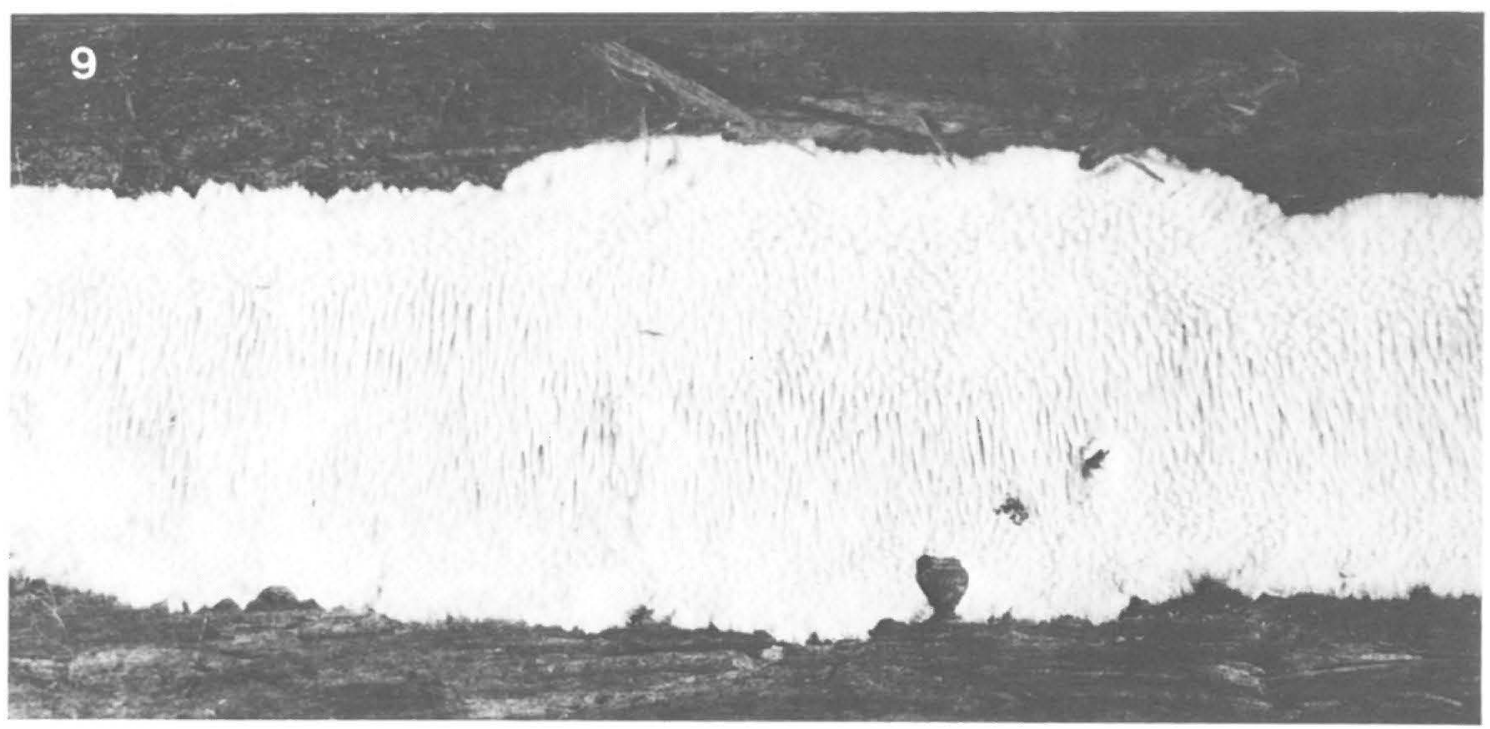

Fig. 9. Dentipellis fragilis (Niemelä 3586), x 1.8.

2-5 $\mu \mathrm{m}$ in diam, hyaline, thin-walled, with clamp connections, rarely branched, IKI-, $\mathrm{CB}+$, interwoven in the context, subparallel in the trama. Gloeoplerous hyphae in the trama 3-7 $\mu \mathrm{m}$ in diam, filled with oily matter and protruding to the hymenium as gloeocystidia which, however, are rather weakly differentiated. Cystidioles narrow, thin-walled, moniliform at their apices. Basidia slender, $25 \times 4 \mu \mathrm{m}$, mostly four-spored but often also with only two sterigmata, with a basal clamp. Spores broadly ellipsoid to subglobose, hyaline, thick-walled, minutely warted, 5-5.5 x 4.2-4.9 $\mu \mathrm{m}$, IKI blue, CB-.

A drawing of the microscopical structure was presented in Niemelä and Saarenoksa (1985). Tortić and Jelić (1977) published a SEM picture of the spores; Capellano and Keller (1978) studied the spore wall layering in the TEM. An extensive description was published by Ginns (1986).

\section{Ecology}

Dentipellis fragilis is a saprophyte of strongly decayed deciduous trees and causes white-rot. It prefers moist and shady growth sites such as the undersides of large fallen trunks. A characteristic environment is a luxuriant thicket or grass-herb forest, and the species is slightly hemerophilous. The ecology has been discussed more extensively by Niemelä and Saarenoksa (1985).

$D$. fragilis favours strongly the southern trees of the genera Fagus and Quercus, and the occurrences on other frondose trees appear to be rather sporadic.

Host list for Norway, Sweden and Finland:

All Norway Sweden Finland countries

\begin{tabular}{lrrrr} 
Fagus sylvatica & 50.0 & 66.7 & 53.6 & - \\
Quercus robur & 11.8 & - & 14.3 & - \\
Carpinus betulus & 8.8 & - & 10.7 & - \\
Tilia & 8.8 & + & 7.1 & - \\
Acer & 5.0 & - & - & 40.0 \\
- platanoides + & & & & \\
- tataricum + & & & & \\
Alnus & 5.0 & - & + & + \\
- glutinosa + & & & & \\
Populus tremula & 5.0 & - & 7.1 & - \\
$\begin{array}{l}\text { Prunus padus } \\
\text { Salix }\end{array}$ & + & - & - & + \\
$\begin{array}{l}\text { Sorbus aucuparia } \\
\text { Host not indicated }\end{array}$ & + & - & + & - \\
Specimens examined & 21 & - & - & + \\
\hline
\end{tabular}

Distribution

Dentipellis fragilis is rare in the Nordic countries, and restricted mainly to the Temperate and Hemiboreal 


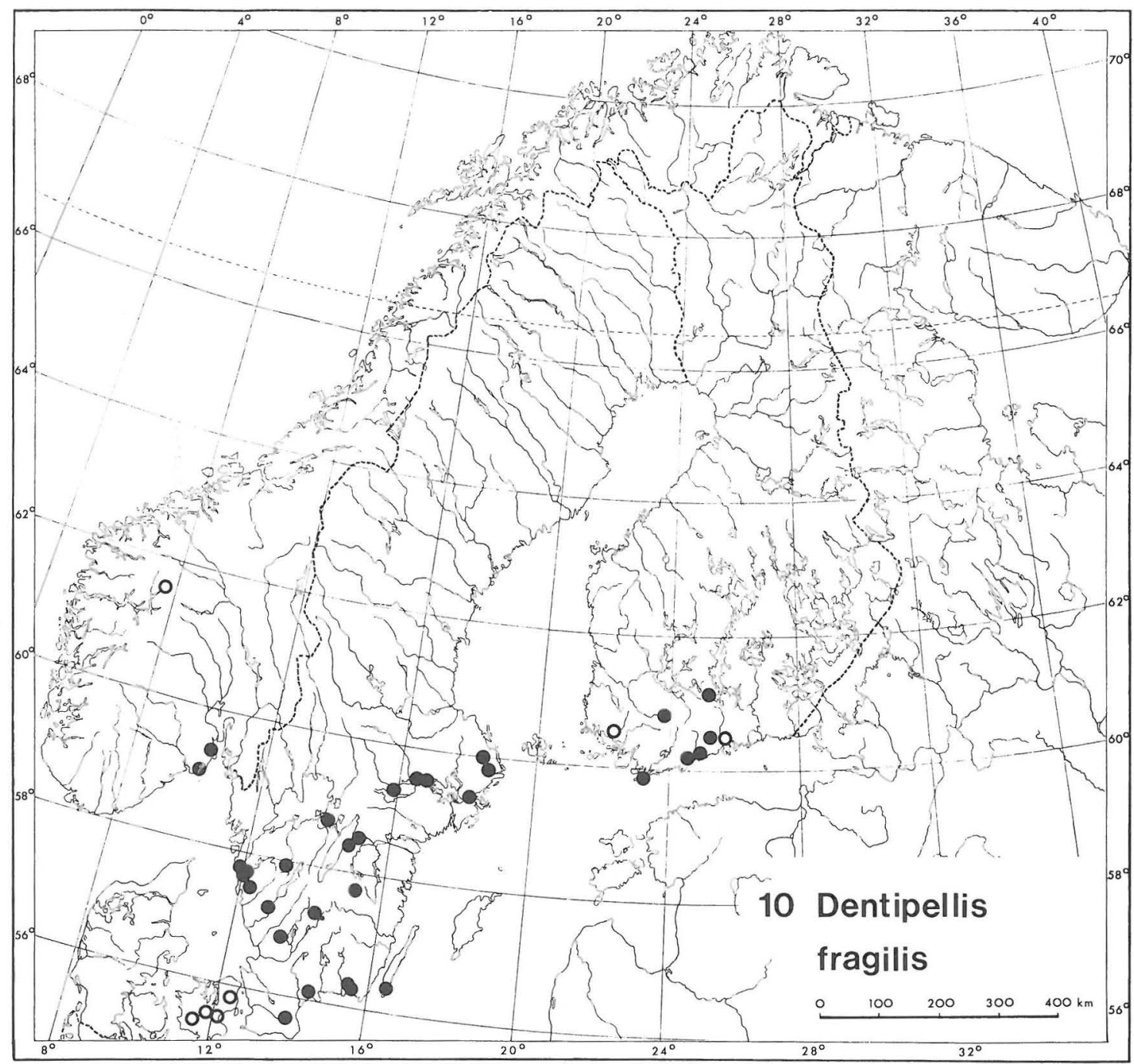

Fig. 10. The distribution of Dentipellis fragilis in northwestern Europe.

zones. A couple of Finnish finds lie on the border of the Southern Boreal zone and two (especially the new record) were made well within that area. There are also finds of the species in the Southern Boreal outlier in the southern tip of Sweden. This gives the impression that the species is climatically hardier than was generally thought, and that the distribution is mostly governed by the distribution of suitable hosts and growth sites. The pattern on the map does not reveal any preferences along the oceanic-continental climatic axis.
D. fragilis in the Nordic countries has been discussed, for example, in the papers of Högholen and Ryvarden (1977), Knudsen and Pedersen (1984), Ingelög et al. (1984), Strid (1983a), Ryman and Holmåsen (1984) and Niemelä and Saarenoksa (1985). In the last-mentioned paper the general distribution was also surveyed on the basis of reports in the literature. In Finland a new record was made after the study of Niemelä and Saarenoksa (1985), on Acer platanoides, fallen trunk in a rich grass-herb forest. 
Finland. Etelä-Häme: Lammi, Biological Station, 19.IX.1986 Niemelä $3586(\mathrm{H})$.

The species deserves attention in Sweden (Ingelög et al. 1984), and in Finland is regarded as endangered (Anon. 1986). In Poland also (Wojewoda \& Ławrynowicz 1986) D. fragilis is included in the list of threatened plants.

D. fragilis has been reported throughout Central Europe (Neubert 1969), but not in the westernmost countries. In the south the species extends to France, the Carpathians and Yugoslavia (Bourdot \& Galzin 1927, Zerova et al. 1972, Tortić \& Jelić 1977), but has not been reported from Spain (Tellería 1980). Scattered occurrences exist throughout the U.S.S.R. to the Soviet Far East (Nikolaeva 1961, Gordienko 1979), and Ginns (1986) confirmed two finds from Japan.

Some confusion has arisen because of two other Dentipellis species, D. leptodon (Mont.) Maas Geest. (D. separans (Peck) Donk, D. subseparans Khara \& Rattan), and $D$. dissita (Berk. \& Cooke) Maas Geest., which differ from $D$. fragilis in having shorter spores. The report of $D$. fragilis in Nepal by Hjortstam and Ryvarden (1984) was amended to $D$. dissita by Ginns (1986). D. leptodon has been found in the Indian Himalayas ('D. subseparans', Rattan 1977; Ginns 1986). Jülich and Stalpers (1980), who reviewed the North American literature very extensively, did not accept the present species there, and some earlier reports in the Central and eastern U.S.A. (Gilbertson 1963, Miller \& Boyle 1943, cf. Donk 1962, Jülich \& Stalpers 1980) should be attributed to the two other species of the genus (Ginns 1986). However, Ginns (1986) in a recent revision confirmed the presence of $D$. fragilis in the Pacific Northwest (Alaska and Washington).

\section{Auriscalpiaceae}

The family Auriscalpiaceae Maas Geest. is characterized by a dimitic hyphal system, gloeocystidia and amyloid, verrucose spores. Maas Geesteranus (1963) originally included the genera Auriscalpium S.F. Gray, Gloiodon Karst. and Lentinellus Karst., in the family and Donk (1964) adopted the concept as such. Later Maas Geesteranus (1976b) added Gloeodontia Boid. and Clavicorona Doty. Jülich (1981) excluded Lentinellus, but widened the scope with a toothed, extra-European genus Stecchericium Reid. Reid (1963) himself emphasized the similarities of Stecchericium to the genera of the Hericiaceae, and Maas Geesteranus (1976a) included it in that family.

The genus Lentinellus (Miller \& Stewart 1971) resembles Auriscalpium and Gloiodon in having strongly amyloid, verrucose spores. The gloeopler- ous hyphae are easy to observe and can be stained with sulphobenzaldehyde (SBA). In Auriscalpium and Gloiodon no reaction could be seen with SBA, and the gloeoplerous hyphae are difficult to see in that reagent, though visible in $5 \% \mathrm{KOH}$ solution.

The spore wall similarities between this group and the Hericiaceae were discussed under that family. In the following text we treat only those genera which contain hydnaceous species.

\section{Auriscalpium vulgare}

Hydnum auriscalpium L., Species Pl. 2: 1178, 1753: Fries, Syst. Mycol. 1: 406, 1821. - Auriscalpium vulgare S.F. Gray, Nat. Arr. British PI. 1: 650, 1821. - For typification and synonyms, see Maas Geesteranus (1959).

Fruit body annual, stipitate or occasionally several fruit bodies arising from a common base, fibrous when fresh, hard when dry. Pileus $0.5-2 \mathrm{~cm}$ across, round or kidney-shaped, plano-convex, covered with bristles, glabrescent with age, dark chestnut brown. Margin entire, when old inrolled and often wavy. Spines up to $3 \mathrm{~mm}$ long, cylindrical down to the base, acute, light brown when young, later covered with a white spore mass and then ashy grey. Stipe 14-55 $\mathrm{mm}$ long, $1-2 \mathrm{~mm}$ in diam, laterally attached to the pileus, cylindrical or slightly flattened, with a bulbous base, hirsute, fibrillose, dark chestnut brown. No specific taste or smell.

Section: Context up to $0.5 \mathrm{~mm}$ thick, duplex with thin, darker hairy layer and thick, rather soft, fibrillose, ochraceous, lower context. Cortical layer thin, black-brown, compact. Stipe layered, with thin dark cortex, covered by hairs, encircling the inner ochraceous context proper.

Hyphal system dimitic. Generative hyphae thinwalled, $1.7-4 \mu \mathrm{m}$ wide in diam, hyaline, with clamp connections. Skeletal hyphae $1.5-4.8 \mu \mathrm{m}$ in diam, thick-walled. Bristles made up of 2.5-4 $\mu \mathrm{m}$ wide, rarely clamped, secondarily septate, branchless, parallel, agglutinated generative hyphae, which are hyaline at the tip, turning brown towards the base. Cortex with 2-4 $\mu \mathrm{m}$ wide, brown, thick-walled, parallel, agglutinated, frequently clamped, branchless generative hyphae. Context proper with interwoven generative and skeletal hyphae. Cortex and context proper of the stipe similar to cortex of the pileus; change from context to trama continuous. Trama with subparallel generative and skeletal hyphae. Gloeoplerous hyphae $3-5 \mu \mathrm{m}$ in diam, with oily contents, protruding into the hymenium as club-like or sharppointed gloeocystidia. Basidia 15-24 × 3-4 $\mathrm{m}$, with basal clamp, four-spored. Sterigmata $3 \mu \mathrm{m}$ long, swollen at the base. Spores ellipsoid, hyaline, minutely verrucose, $4-7 \times 4-5 \mu \mathrm{m}$, IKI blue, CB-. 

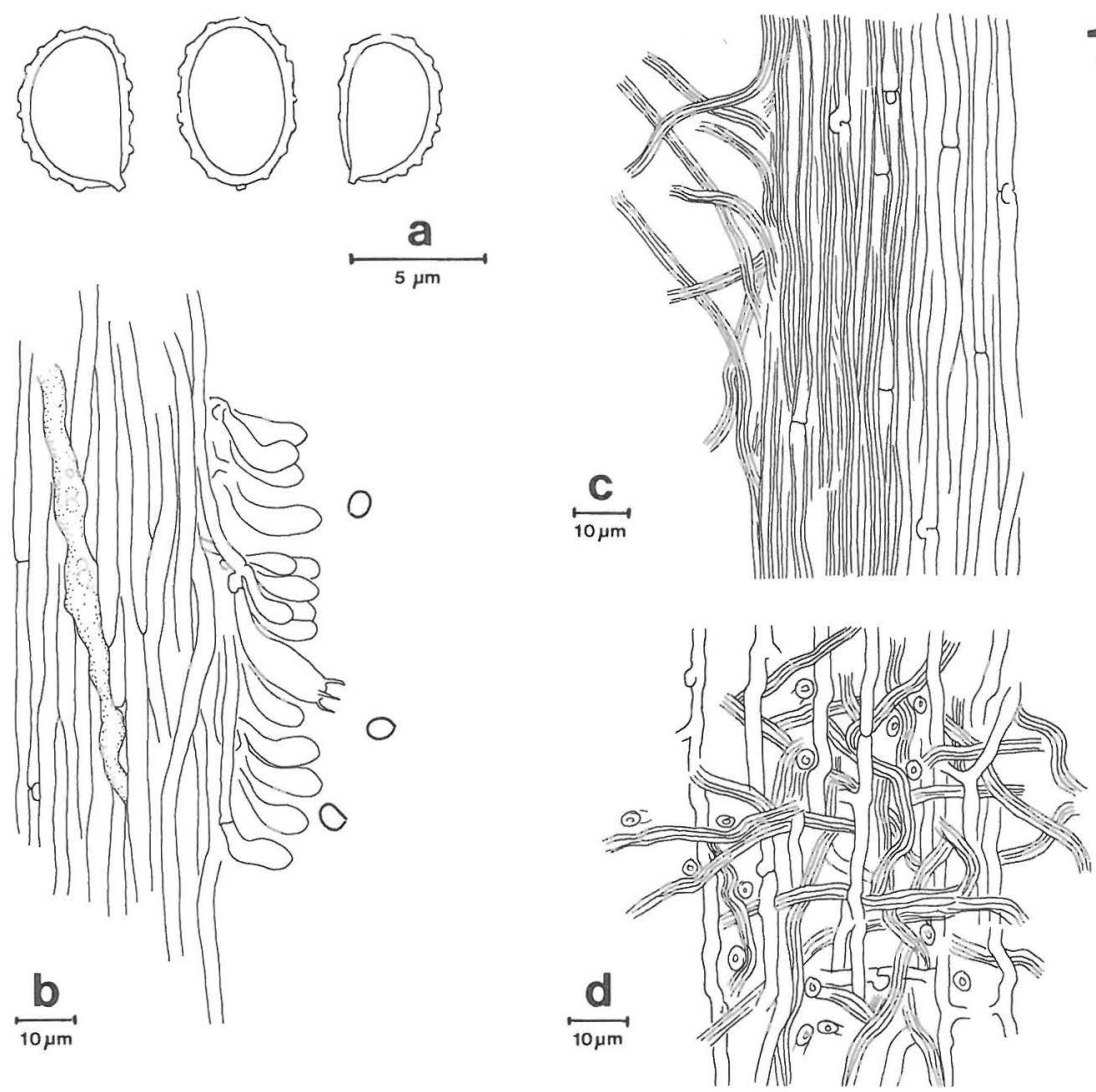

11

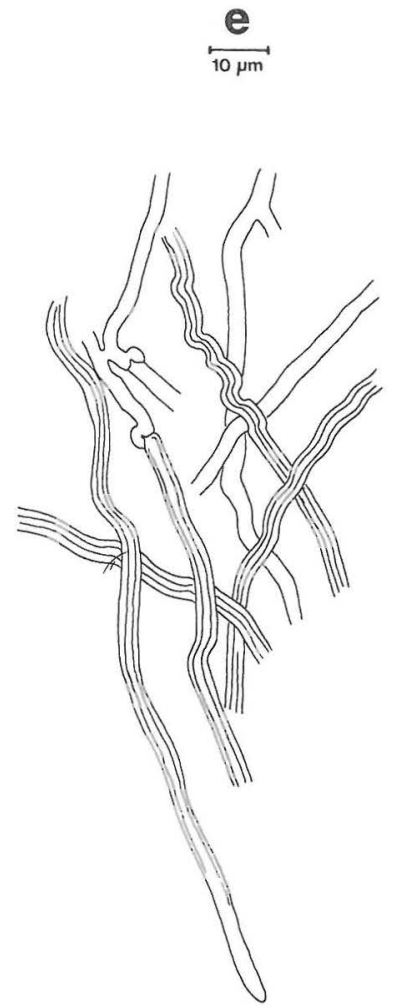

Fig. 11. Auriscalpium vulgare. a) spores, b) spine in vertical section, c) stipe surface in longitudinal section, d) stipe medulla in longitudinal section, e) contextual hyphae (Saarenoksa 48282). Drawn in IKI.

A. vulgare is easily identified by its growth on cones and unmistakable appearance. The colour of the fruit body and the hairiness of the cap vary with the age. Old pilei tend to be dark cigar brown and almost glabrous, while young ones are light chestnut brown and covered with bristles. The size variation is very small. According to the literature, the diameter of the pileus is $0.5-2 \mathrm{~cm}$ (Nikolaeva 1961, Maas Geesteranus 1971, Phillips 1981, Jülich 1984, Ryman \& Holmåsen 1984), which fits well with our measurements. However, according to Phillips (1981) and Jülich (1984), the length of the stipe is up to $140 \mathrm{~mm}$, which is over twice as long as in the Fennoscandian material.

\section{Ecology}

Auriscalpium vulgare usually grows (roughly $90 \%$ of the finds) on the cones of Pinus sylvestris, but ca.
$10 \%$ of the Fennoscandian collections originate from Picea abies, which is more than is generally reported. There may be several fruit bodies growing on the same cone, but such cases often include dead caps from the preceding year. So the fungus grows for several years in a single cone.

A characteristic habitat is luxuriant grass-herb forest with humid and shady conditions in the field layer. The cones are usually at least partly buried among mosses and forest litter, and the substrate is therefore inconspicuous and easily overlooked. Fruit bodies have been collected all the year round, but according to the dates of the collections the growth season is from August to October.

\section{Distribution}

Auriscalpium vulgare is distributed fairly evenly over the southern and central parts of the study area, and 
Host list for the Nordic countries:

All Denmark Norway Sweden Finland countries

\begin{tabular}{lrrrrr} 
Pinus sylvestris & 90.4 & 100 & 87.7 & 87.2 & 91.0 \\
Picea abies & 9.6 & - & 12.2 & 12.8 & 9.0 \\
Host not indicated & 199 & & & & \\
Specimens examined & 419 & 26 & 62 & 155 & 176 \\
\hline
\end{tabular}

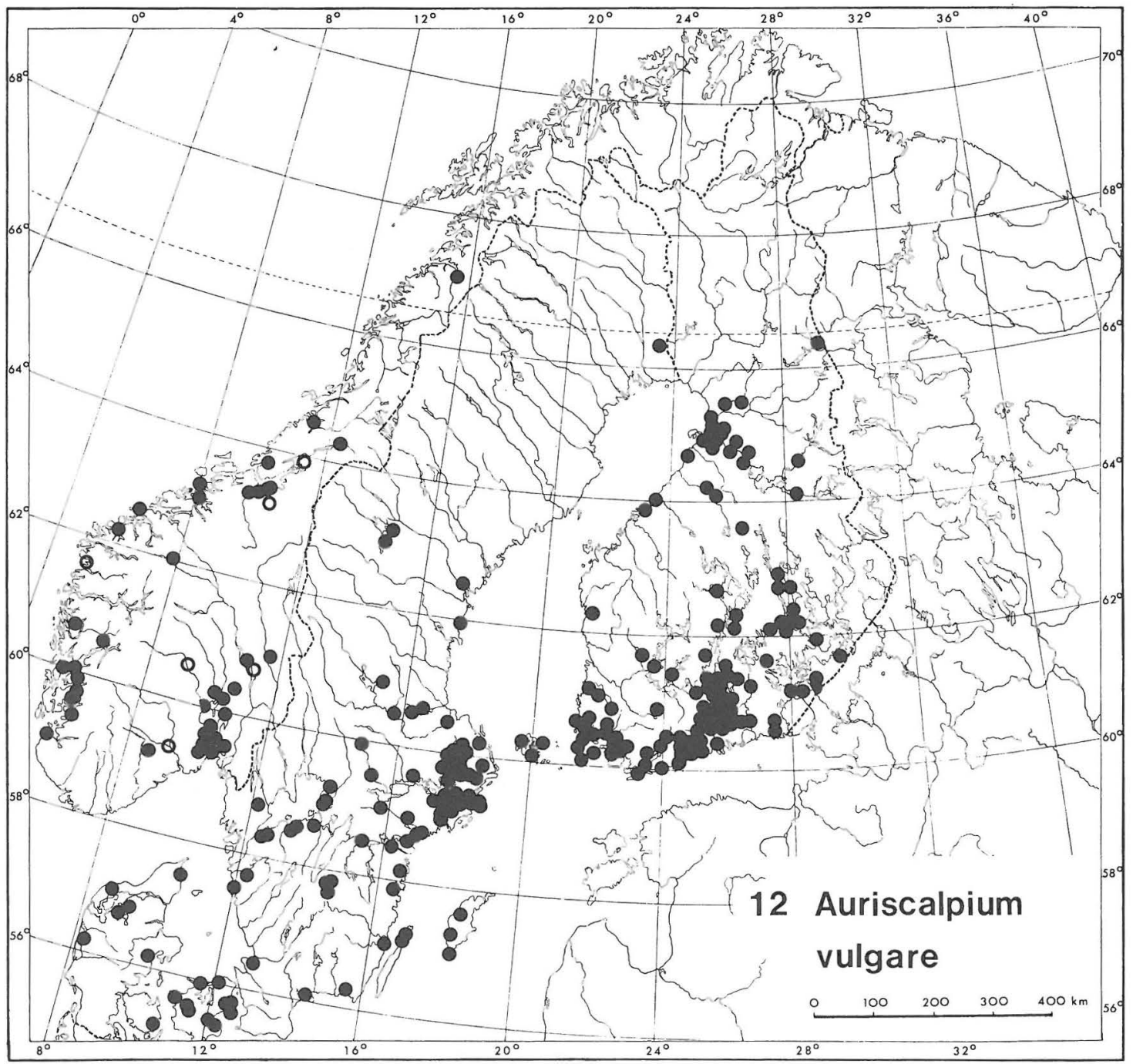

Fig. 12. The distribution of Auriscalpium vulgare in northwestern Europe. 
is rare only in the Northern Boreal zone.

In Denmark the species is common in the whole of the country (Lind 1913). Lange (1974) reported its absence from the western part of Jutland and attributed it to the soil conditions. In the present map no such boundary is apparent in Denmark, and Lange's report was evidently caused by too small a number of records. In Norway, Gulden \& Stordal (1973) and Eckblad \& Gulden (1974) consider A. vulgare to be occasional. Its northernmost record in the study area is at Otterøya near Namsos, $64^{\circ} 37^{\prime} \mathrm{N}$. Blytt (1905) reports it from Akershus (Bærum) and Sogn og Fjordane (Svanøy), and Egeland (1913) from Akershus (Gaustad) and Oslo. A distribution map was published by Eckblad and Gulden (1974). In Sweden the species is fairly common in the southern parts of the country, but becomes rare north of the Hemiboreal zone. The northernmost Swedish find is from Norrbotten (Matarengi), which is in the Middle Boreal zone, and the two inland collections from Central Sweden also originate from this zone.

In Finland A. vulgare is common in the southern and central parts, but completely absent from Lapland north of the Arctic Circle. The concentration of the collections near Helsinki, Turku and Oulu presumably reflects the proximity of the universities and the activity of their mycologists. Another explanation of the pattern would be a slightly hemerophilous growth habit, but that is less probable. The species is most likely uniformly distributed, but overlooked because of its habit of hiding in the forest floor.

The total distribution in northwestern Europe is fairly southern. A. vulgare is indifferent to the climatic humidity: it is found both on the highly oceanic western Norwegian coast and in the more continental parts of eastern Finland.

According to Jülich (1984), the species is common all over Europe, including the westernmost countries; Maas Geesteranus (1959) mentioned it as common on pine cones in the Netherlands. Lange (1974) published the general distribution in western, central and northern Europe, and Kreisel et al. (1980) mapped the species in the German Democratic Republic. Klán and Kotilová-Kubicková (1982) reported it from the Caucasus.

The world distribution of the species is remarkably wide. Plank (1978) mentions Eurasia, North America and South America. In North America it is known from Canada (Pomerleau 1980) to Mexico (Coker \& Beers 1951), and it is widely distributed in the U.S.A. (Coker \& Beers 1951, Lincoff 1981). The easternmost Asian locality mapped by Nikolaeva (1961) lies by lake Baikal, but Maas Geesteranus (1971) has studied material from Pakistan, India, China and Japan.

\section{Gloiodon strigosus}

Hydnum strigosum Swartz, Kongl. Vetensk. Acad. Nya Handl. 31(3): 250, 1810: Fries, Syst. Mycol. 1: 414, 1821. - Gloiodon strigosus (Swartz: Fr.) Karsten, Medd. Soc. F. Fl. Fenn. 5: 42, 1879.- For synonyms, see Maas Geesteranus (1974). Type: not designated, see Banker (1913). According to Swartz (1810), H. strigosum was found in Sweden, Västmanland: Sätrabrunn, and Karlberg between Ramnäs and Fläckebo.

Fruit body annual, often emerging from remnants of earlier years, resupinate, effused-reflexed or pileate, solitary or more often consisting of several imbricate caps growing at the edges of a wider resupinate area, ochraceous or greyish brown, darkening with age to sepia or dark cigar brown; soft when fresh, brittle when dry. Pileus up to $3 \mathrm{~cm}$ in diam, broadly attached, covered with stiff, shaggy hairs, which form flattened bundles at the margin of the pileus. Resupinate part up to $6 \times 4 \mathrm{~cm}$ wide. Spines up to $1 \mathrm{~cm}$ long, cylindrical, acute, pale greyish brown when young, when old or dry covered with white spore mass and then dark ash grey. No specific taste or smell.

Section: Context duplex. Tomentum consisting of dark cigar brown, loosely interwoven, shaggy bristles. Separating layer thin, black-brown, compact. Context thicker than other layers, soft and fibrillose, light brown; enclosures of context often found within the tomentum. Subiculum in resupinate parts $0.5 \mathrm{~mm}$ thick, with clearly marked, blackbrown separating layer. Trama of the spines light brown, homogeneous.

Hyphal system dimitic. Generative hyphae 2$5 \mu \mathrm{m}$ in diam, thin-walled, with clamp connections. Skeletal hyphae $2-4 \mu \mathrm{m}$ in diam, thick-walled. Bristles made up of parallel, agglutinated generative hyphae. Cortex resembling tomentum in its hyphal structure, with predominantly brown-walled, parallel, agglutinated, generative hyphae. Context a subparallel network of generative and skeletal hyphae, changing without zonation into the trama. Gloeoplerous hyphae difficult to observe, $3-5 \mu \mathrm{m}$ in diam, oil-filled, protruding into the hymenium as club-like or sharp-pointed gloeocystidia. Basidia 15-25 x 5$7 \mu \mathrm{m}$, with a basal clamp, four-spored. Spores subglobose, hyaline, minutely verrucose, $4-6 \times 3-4 \mu \mathrm{m}$, IKI blue, CB-.

Gloiodon strigosus resembles Auriscalpium vulgare in many details. Common characters are the shaggy hairs covering the pileus as a tomentum, the cigar brown colour of the pileus and context, the duplex structure with a cortical layer, and the colour of the spines. When growing on the upper side of a fallen tree, the pilei of $G$. strigosus have constricted bases, and may even be substipitate. In the microscope the similarities to Auriscalpium vulgare are 


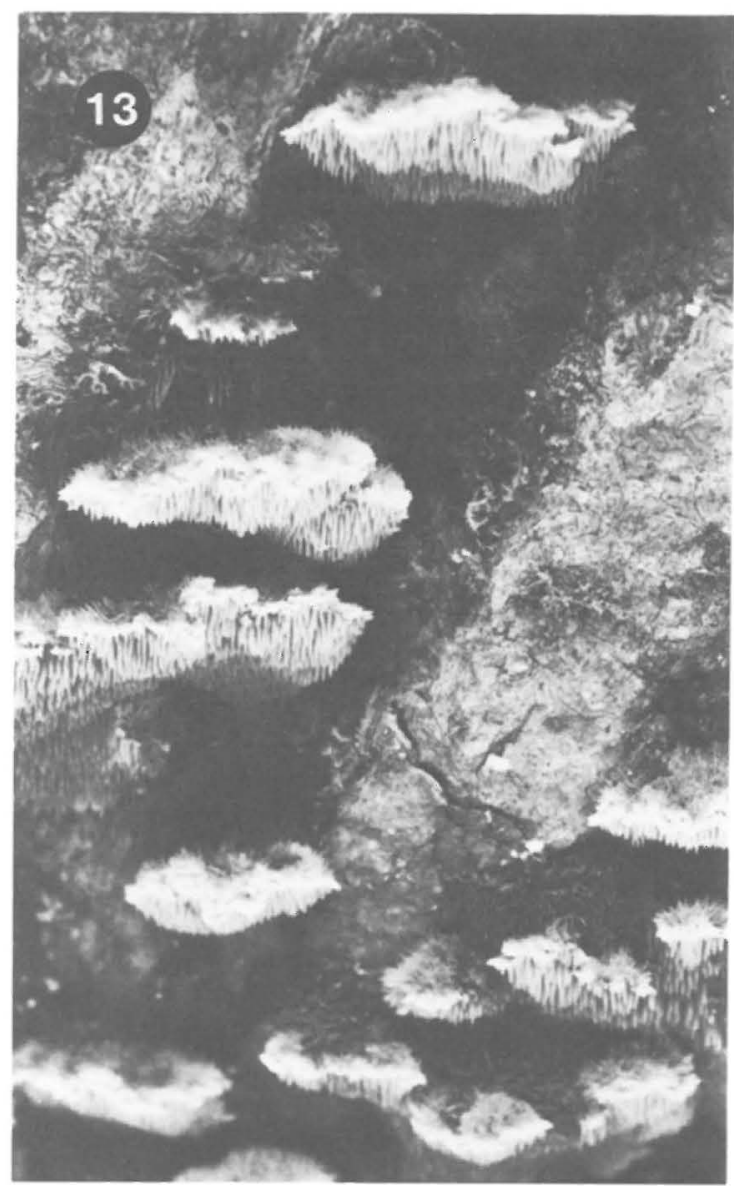

Fig. 13. Gloiodon strigosus (Niemelä 3273), x 1.

even more obvious: dimitic hyphal structure, gloeocystidia, and the characters of the spores. These two species could well be placed in a single genus, because the chief differences are merely morphological and are moreover relatively small.

The most detailed description and discussion of the species has been published by Jahn and Sturm (1983).

\section{Ecology}

Gloiodon strigosus grows on decorticated, fallen trunks of deciduous trees, often underneath trunks which are covered by mosses, and very often on broken trunk ends. A characteristic growth site is luxuriant spruce or grass-herb forest, where old decayed trunks are left on the ground. Numerous finds were also made in spruce-dominated moist heath for- ests. The areas of the trunks where the fruit bodies grow consist of fairly hard wood.

The species seems to favour a very humid microclimate. Harrison (1973b) reports that it grows on water-logged wood, though this does not fit with our experience. In the cases that we saw the trees were normally moist and lying on a moss-covered forest floor. The strong shade of a dense tree stand seems to be more essential to the well-being of the species.

Aspen is the general favourite of the fungus in the Nordic countries, though there were more collections from alders in Norway. G. strigosus is saprophytic, causing white-rot (Jahn 1979). In Finland, however, the species was found once on a living aspen, on a large scar formed by the fall of another trunk, which was widely attached at its base to the standing one; the fungus also fruited abundantly at the base of the fallen trunk.

G. strigosus is clearly hemerophobic. It has no economic importance, but is an interesting example of a species that may be endangered due to its rarity and preference of old forests. Most of the recent finds are from national parks or other forest reserves. Even slight forest management can affect the microclimatic conditions and change them unfavourably for the species. In both Sweden (Ingelög et al. 1984) and Finland (Anon. 1986) the species has been considered to deserve attention, due to its rarity and even more to its vulnerable ecology.

Host list for Norway, Sweden and Finland:

All Norway Sweden Finland countries

\begin{tabular}{|c|c|c|c|}
\hline Populus tremula & 45.8 & 30.0 & 38.5 \\
\hline $\begin{array}{l}\text { Alnus } \\
\text { - incana } 8.3 \\
\text { - glutinosa } 4.2\end{array}$ & 22.9 & 40.0 & 26.9 \\
\hline $\begin{array}{l}\text { Salix } \\
\text { - caprea }+ \\
\text { - pentandra }+\end{array}$ & 14.6 & + & 15.4 \\
\hline Prunus padus & 10.4 & - & 15.4 \\
\hline Ulmus & 4.2 & 20.0 & + \\
\hline Betula & + & - & + \\
\hline Host not indicated & 18 & & \\
\hline Specimens examined & 66 & 17 & 33 \\
\hline
\end{tabular}

Distribution

Gloiodon strigosus is distributed throughout the Boreal zone in Fennoscandia, but is considered rare or 

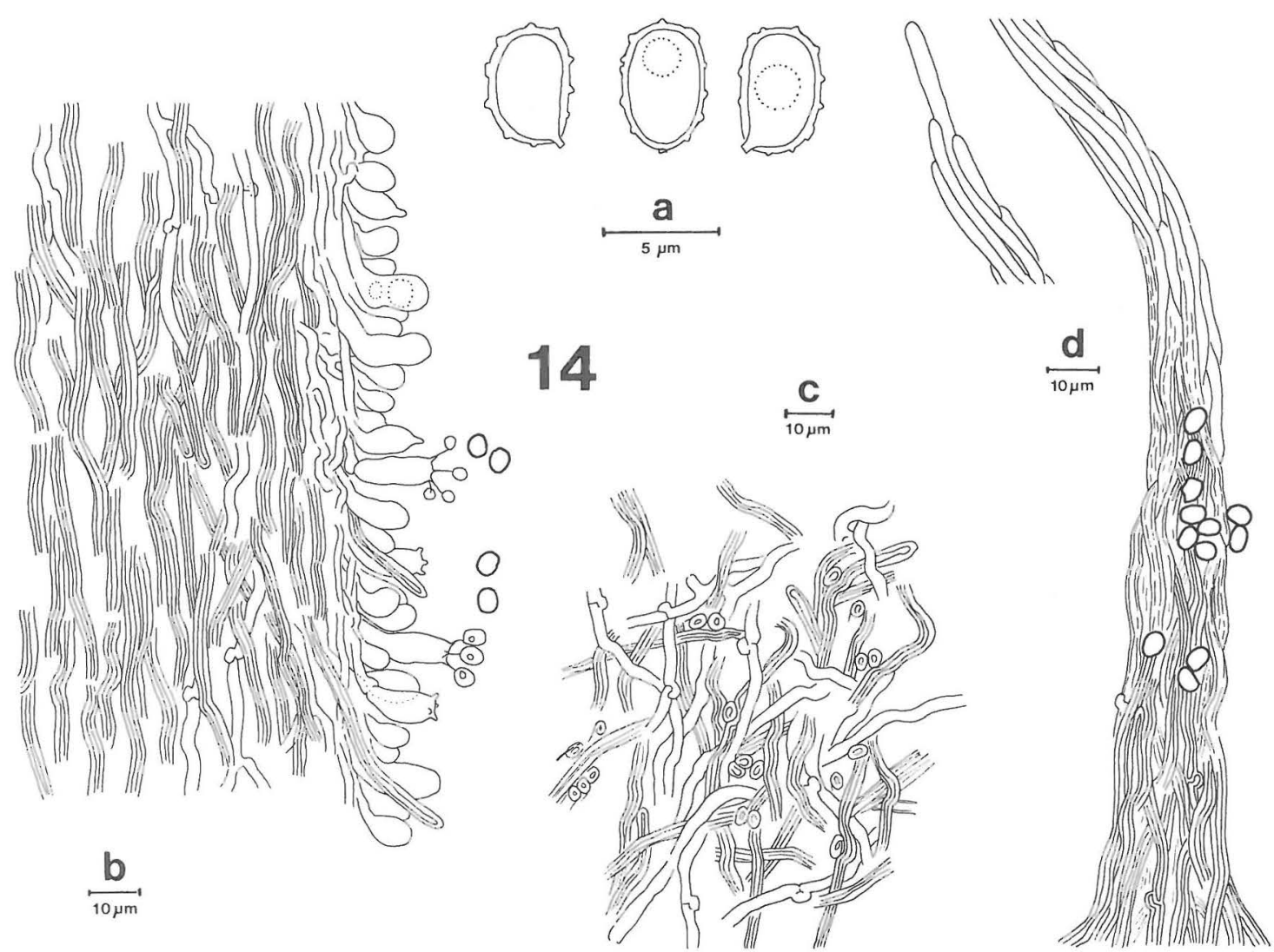

Fig. 14. Gloiodon strigosus, a) spores, b) spine in vertical section, c) contextual hyphae, d) bristle from the pileal tomentum with attached spores (Niemelä 3273). Drawn in IKI.

very rare in every country. According to Ryvarden (1971), no special pattern is apparent from the distribution map. Our map also reveals even, scattered occurrence over almost the whole area, excluding only the Temperate zone. Numerous finds have been made both on the highly oceanic western coast of Norway and in the slightly continental interior of Finland.

In Norway, G. strigosus is very rare and scattered finds have been made from Telemark in the south to Nordland in the north. Egeland $(1911,1913)$ reported it from Oslo and Bærum. Ryvarden (1971) published a map covering the Nordic countries; our new map gives a more detailed picture, but the basic impression, localities scattered sparsely over the whole area, still remains. Ingelög et al. (1984) published a revised map for Sweden, where there are 20 localities, extending from Småland to Torne Lappmark. Strid (1975) reported the species from Central Sweden. It does not occur in Denmark.

In Finland only 11 localities are known, but in some areas (Etelä-Häme: Lammi, Kotinen virgin forest, and Kainuu: Puolanka, Paljakka National Park) the fungus has been observed in many separate places. The northernmost Finnish find is from Kemin Lappi: Savukoski in the interior of the Lapland fjelds (coll. 1986 Pertti Renvall, H).

The general distribution of G. strigosus is mainly Boreal or Oroboreal. Järva and Parmasto (1980) give one locality from the Estonian S.S.R.; Wojewoda and Eawrynowicz (1986) consider that the species is probably extinct in Poland. Jahn and Sturm (1983) reported the first find in Central Europe, in the Bavarian Alps, in an Oroboreal montane zone. Jülich (1984) added Czechoslovakia, France and Hungary. Jahn and Sturm (1983) also listed the Carpathians of Romania and the U.S.S.R. Zerova et al. (1972) mentioned several Ukrainian localities by the tributaries of the Dnepr River north of Kiev. In Siberia the species has been found along the upper Irtysh, $\mathrm{Ob}$ and Yenisei Rivers (Nikolaeva 1961, Jahn \& Sturm 


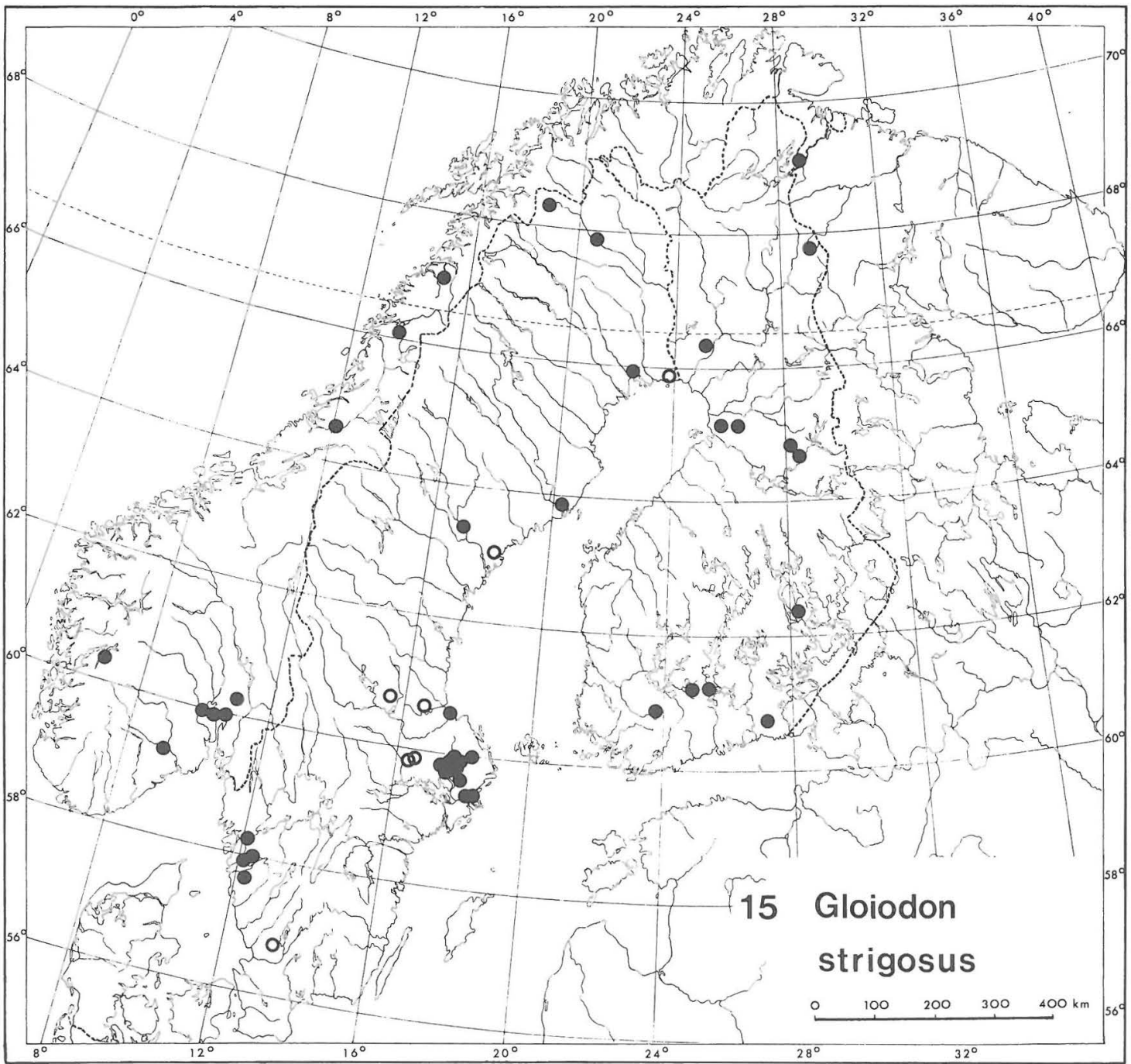

Fig. 15. The distribution of Gloiodon strigosus in northwestern Europe.

1983) and in the Soviet Far East (Lyubarskij \& Vasilyeva 1975). In Herb. L there is a specimen from Uttar Pradesh, India (Jahn \& Sturm 1983). In North America the fungus is found in both Canada (Pomerleau 1980) and the U.S.A. (Banker 1913, Harrison 1973b).

\section{Climacodontaceae}

This family has no close connections with those discussed above. When describing the family, Jülich
(1981) characterized it by its monomitic hyphal system, the presence of cystidia or gloeocystidia, and the inamyloidity of the spores. He included the genera Climacodon Karst. and Donkia Pil., but the latter may be only a synonym of the former.

Climacodon has been a difficult genus in the systematics of the Aphyllophorales, and both Maas Geesteranus (1971) and Donk (1964) kept it in a group of the unclassified Hydnaceae which could not conveniently be placed in any of the existing families. For the time being, the solution of Jülich (1981) can be accepted; unfortunately it leaves the connections with the other Aphyllophorales as uncertain as ever. 

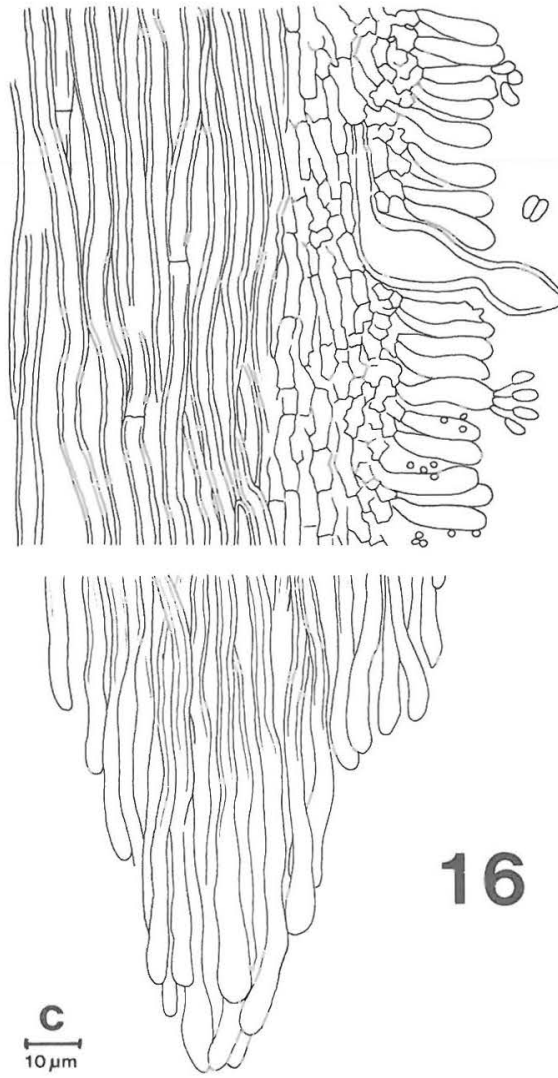
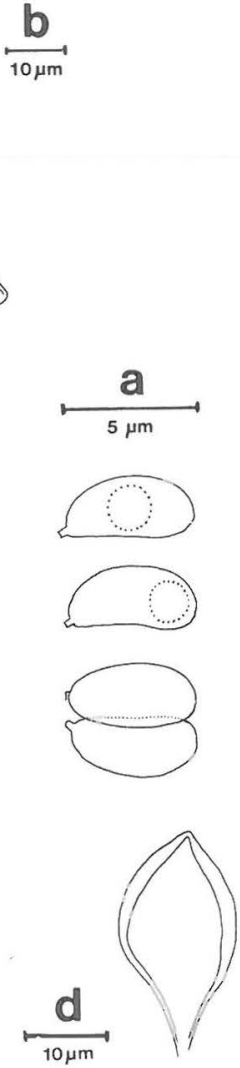
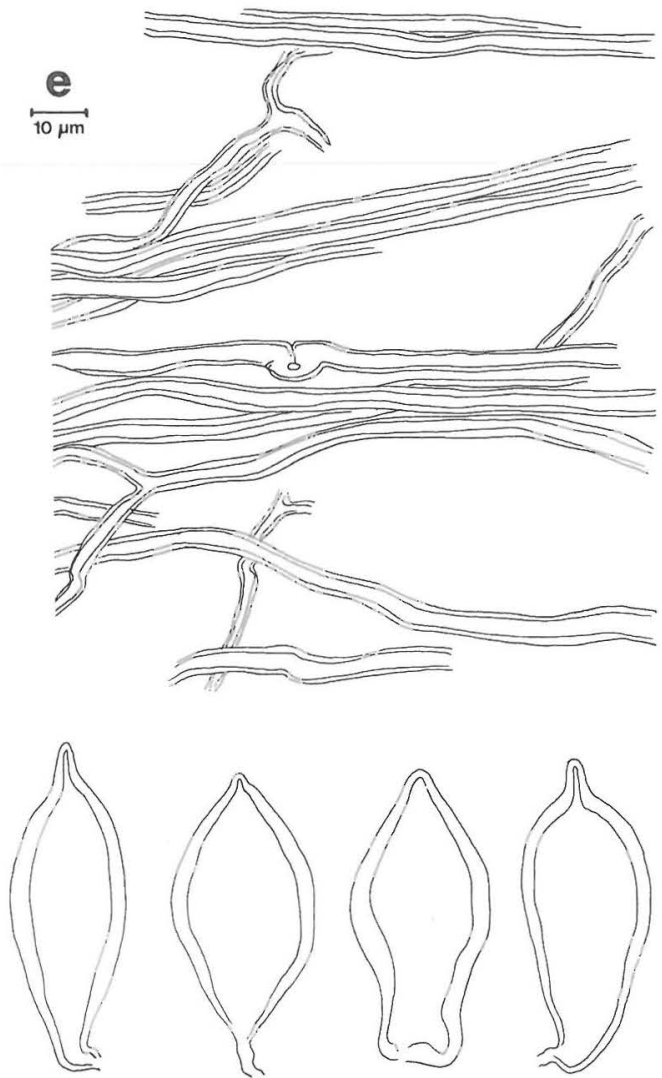

Fig. 16. Climacodon septentrionalis. a) spores, b) spine trama, subhymenium and hymenium in vertical section, c) spine apex, d) cystidia, e) upper context (a-c Niemelä 2318; d-e von Weissenberg 300, freeze dried). Drawn in CB.

It could be worth while to make a comparison between this genus and the poroid Climacocystis Kotl. \& Pouz.

\section{Climacodon septentrionalis}

Hydnum septentrionale Fries, Syst. Mycol. 1: 414, 1821. Climacodon septentrionalis (Fr.) Karst., Rev. Mycol. 3(9): 20, 1881. - Type locality: 'Suecia superior' (Fries 1821), meaning mountainous or otherwise elevated area of Sweden; Maas Geesteranus' (1974: 566) interpretation 'North Sweden' is inappropriate in the light of our distribution map. Type: not designated.

Fruit body annual, often persisting (as dead) till the following spring, made up of several layers of imbricate pilei, joined together by a basal plate, cream or chamois yellow when fresh, becoming brownish when dry. Total fruiting area up to $50 \mathrm{~cm}$ tall and $20-25 \mathrm{~cm}$ broad. Pileus up to $10 \mathrm{~cm}$ wide, projecting $3-6 \mathrm{~cm}$ from the substrate, $1-2 \mathrm{~cm}$ thick at the base, becoming thinner towards the margin. Upper surface rough. Margin sharp, inrolled when dry. Spines up to $12 \mathrm{~mm}$ long, cylindrical, acute, creamy yellow when fresh, becoming brownish and fragile when dry. Odour sour when fresh, becoming strong and unpleasant during drying, like rancid fat. Taste bitter.

Section: Context up to $15 \mathrm{~mm}$ thick, strongly fibrous and tough, sometimes with darker hygrophanous zones but not duplex, changing into trama without zonation.

Hyphal system monomitic. Generative hyphae 2-10 $\mu \mathrm{m}$ in diam, thin-walled, hyaline, variably clamped, branched, subparallel in the context, parallel in the trama. Septa of the context hyphae with single or multiple clamp connections; tramal hyphae clampless. Cystidia thick-walled, subulate or bottleshaped, often apically encrusted. Basidia slender, 15-20 × 5-7 $\mu \mathrm{m}$, without a basal clamp, fourspored. Spores ellipsoid, smooth, hyaline, 4.5-5 $\mathrm{x}$ $1.8-2.5 \mu \mathrm{m}, \mathrm{IKI}-, \mathrm{CB}-$. 

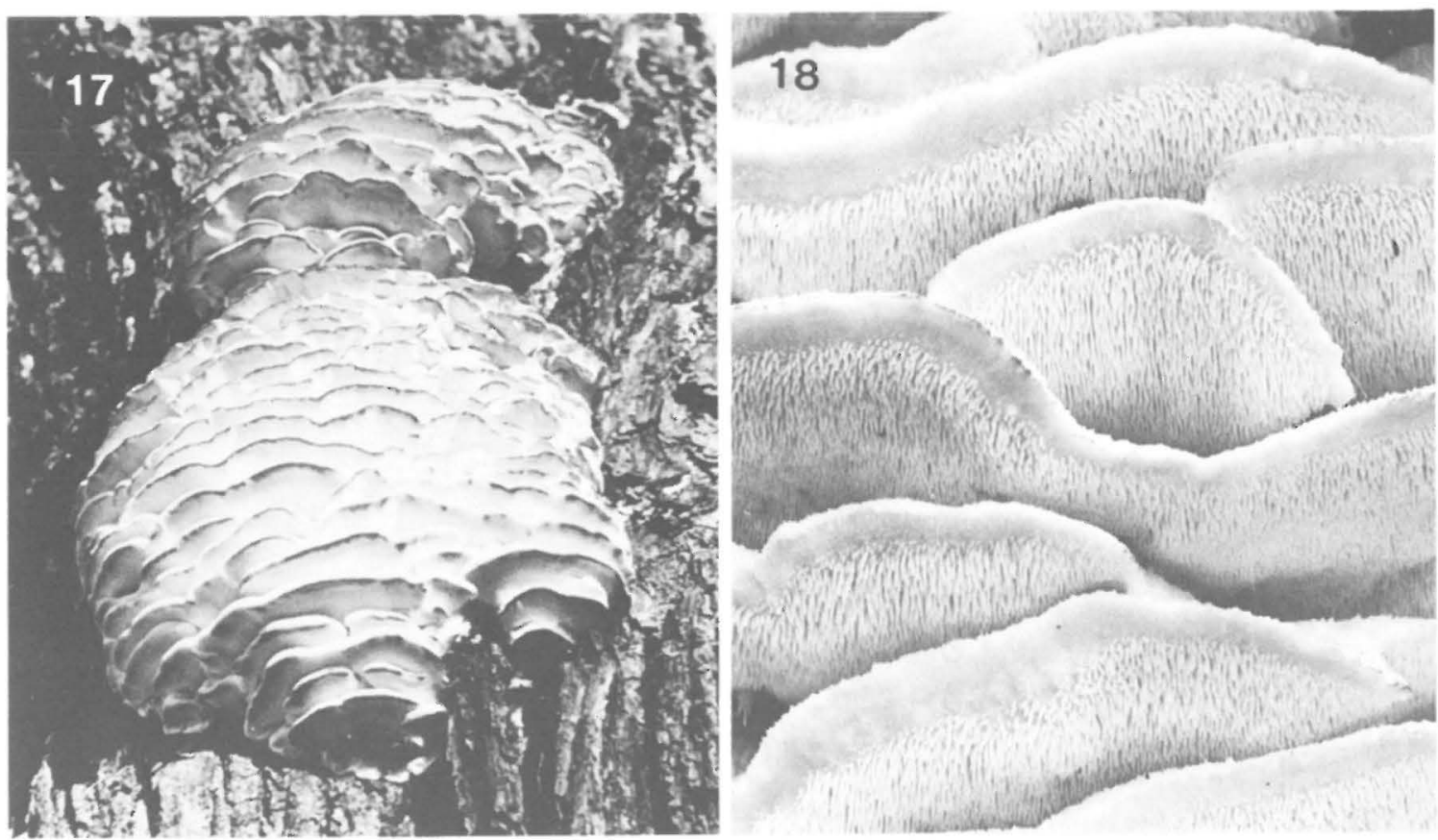

Figs. 17-18. Climacodon septentrionalis. - 17: Habit picture (1967 Niemelä, no herb. spec.), ca. x 0.3. - 18: Lower surface (Niemelä 2274), x 1.2.

C. septentrionalis is morphologically variable. The pilei can be very thin, especially when they are reaching their maximal size. At the beginning of growth, when the pilei are thick and tuberculate, $C$. septentrionalis may be mistaken for Creolophus cirrhatus, but the structure of the context is quite different.

C. septentrionalis resembles the polypore Climacocystis borealis (Fr.) Kotl. \& Pouz. surprisingly closely. The colour, gross morphology and consistency of the two species are similar, they are both very strongly fibrous inside, and the monomitic hyphal structure, cystidia (this similarity also noted by Domański 1981) and other microscopic characters show a close resemblance. The cultures of both species produce chlamydospores and they give similar results in laccase and peroxidase tests (Stalpers 1978). C. borealis has often been regarded as a brown-rot fungus, but in fact it causes a white-rot (Stalpers 1978, Jülich 1984, Gilbertson \& Ryvarden 1986), like C. septentrionalis. Bendiksen (1986) and Courfenay \& Burdsall (1982) even listed C. borealis under the generic name Climacodon, but they were unintentional and invalid combinations (Bendiksen in litt., Burdsall in litt.), caused by the similarity of the two generic names. A closer comparison of Climacocystis and Climacodon would be interesting. The production of chlamydospores, type of cystidia, fibrous structure and hence somewhat fan-shaped pilei, and many other features also bring to mind the genus Oligoporus in the sense of Erkkilä and Niemelä (1986).

\section{Ecology}

Climacodon septentrionalis prefers environments which are affected by human activity: parks, old manor gardens, graveyards, tree-lined streets in towns and old villages. It is an aggressive parasite and causes some economic losses by attacking old, living park trees, especially maples. It continues to grow for a few years after the host has died. The fruiting season is in the autumn (September to November), but the persisting fruit bodies often remain identifiable till the following spring and summer.

Erkkilä and Niemelä (1986) classified the polypores in the city of Helsinki into three categories, according to their preference of urban or rural habitats. Species which prefer urban environments were called 'centric', those which avoid human influence 'peripheral', and the third group comprised 'indifferent' species, found in every type of environment. In that classification the hemerophilous $C$. septentrionalis would be a good example of a species having a cen- 


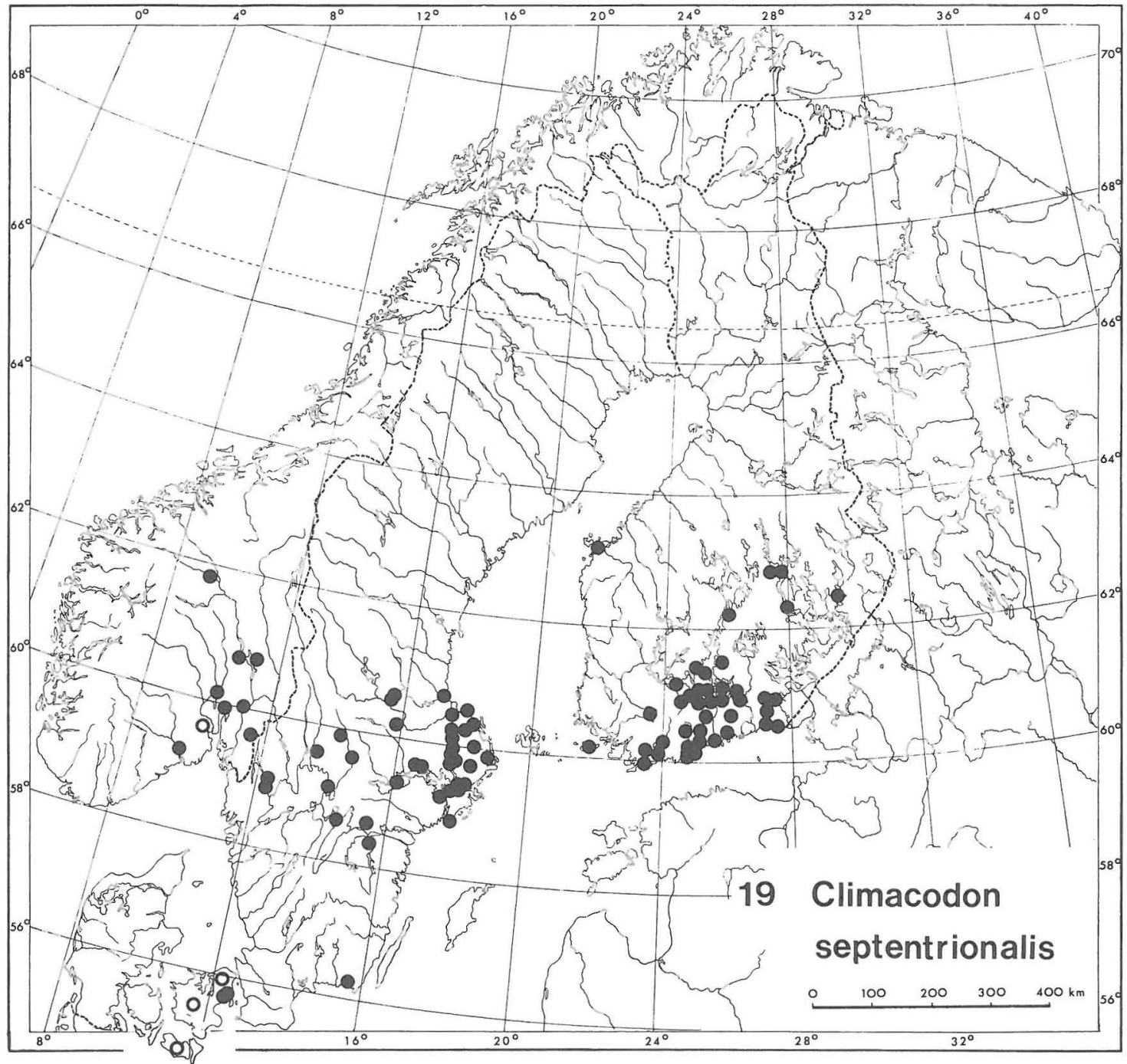

Fig. 19. The distribution of Climacodon septentrionalis in northwestern Europe.

tric microdistribution.

The commonest (ca. 50\%) host tree in northwestern Europe is Acer platanoides. The host range of $C$. septentrionalis is very wide, and almost all common deciduous park trees can be infected by it, both indigenous and exotic. The following genera are reported from Fennoscandia: Acer, Aesculus, Alnus, Betula, Corylus, Crataegus, Populus, Prunus, Quercus, Sorbus, Tilia and Ulmus. In Denmark it grows almost solely on Fagus sylvatica (Knudsen \& Pedersen 1984), but has also been recorded on Aesculus hippocastanum (Winge 1945). Blytt (1905) also reported Fagus sylvatica in Norway.
Host list for Norway, Sweden and Finland:

All Norway Sweden Finland countries

$\begin{array}{lrrrr}\text { Acer platanoides } & 49.7 & 20.0 & 35.9 & 61.8 \\ \text { Betula } & 14.6 & 20.0 & 7.8 & 18.5 \\ \text { - pendula 3.5 } & & & & \\ \text { Tilia } & 11.1 & - & 9.4 & 13.4 \\ \text { - cordata 1.2 } & & & & \\ \text { - xvulgaris } 1.2 & & & & \end{array}$




\begin{tabular}{|c|c|c|c|c|}
\hline Aesculus hippoc. & 8.8 & - & 23.4 & - \\
\hline $\begin{array}{l}\text { Populus } \\
\text { - balsamifera } 3.5 \\
\text { - tremula } 1.8 \\
\text { - nigra }+\end{array}$ & 8.8 & 20.0 & 17.1 & 2.1 \\
\hline $\begin{array}{l}\text {-tacamahaca + } \\
\text { Ulmus } \\
\text {-glabra }+\end{array}$ & 2.3 & + & 3.1 & + \\
\hline $\begin{array}{l}\text { - montana + } \\
\text { Alnus } \\
\text { - glutinosa }+\end{array}$ & 1.2 & + & - & + \\
\hline $\begin{array}{l}\text { Sorbus } \\
\text { - aucuparia + } \\
\text { - intermedia + }\end{array}$ & 1.2 & - & + & + \\
\hline Corylus & + & + & - & - \\
\hline Crataegus & + & - & + & - \\
\hline Prunus padus & + & + & - & - \\
\hline Quercus robur & $\begin{array}{c}+ \\
22\end{array}$ & - & - & + \\
\hline Specimens examined & 193 & 14 & 76 & 103 \\
\hline
\end{tabular}

\section{Distribution}

From the North European point of view, the specific name of $C$. septentrionalis is not very well selected: the species is distributed in the southern half of the study area only. In Denmark it is very rare and considered to be endangered there. According to Knudsen and Pedersen (1984), the species is living at the southern margin of its continuous distribution in Denmark. In Norway, too, it is rare and known from only about 10 localities. It is fairly common in southern Central Sweden, but, as with Creolophus cirrhatus, almost no records were obtained from the southern tip. In Finland C. septentrionalis is fairly common in the Hemiboreal and Southern Boreal zones, and the northernmost locality in the whole area lies in coastal Finland, Etelä-Pohjanmaa: Vaasa.

The northern limit of the fungus in northwestern Europe falls neatly within the Southern Boreal zone. The absence from western Norway and Denmark indicates a preference of a slightly continental climate, and the distribution patterns in Sweden and Finland support that picture, too.

Though southern in our study area, C. septentrionalis shows a northern trend in the total distribution in Europe. It is rare in the Federal Republic of Germany (Schmid-Heckel 1985) and Kreisel (1961, 1987) reported only a few localities in the German Democratic Republic. Järva and Parmasto (1980) published a few Estonian localities. About 10 occurrences are known in Poland (Wojewoda 1973; map included). Jülich (1984) listed records from Austria,
Belgium, Czechoslovakia and France, and we have seen a collection from Vienna in Austria (coll. 1979 Uwe Passauer, T.N.). The southernmost report in Europe is from Yugoslavia (Tortić \& Jelic 1977).

The distribution of $C$. septentrionalis extends from the European U.S.S.R. to Asia (mapped by Nikolaeva 1961), south to Kazakhstan (Švarcman 1964) and eastwards to the Soviet Far East (Zerova et al. 1972, Lyubarskij \& Vasilyeva 1975). Maas Geesteranus (1971) has studied specimens from China, Japan, the Philippines and the Malay Peninsula, the two last-mentioned being found surprisingly far south.

In North America, C. septentrionalis occurs in Canada (Pomerleau 1980) and the northeastern U.S.A. (Coker \& Beers 1951, Lindsey \& Gilbertson 1978, Lincoff 1981).

Acknowledgements. The curators of the numerous herbaria listed on pages 45 and 52 are thanked for loans. Prof. Leena Hämet-Ahti (Helsinki) helped in many ways in the preparation of the revised map of the vegetational zones. We are indebted to Dr. R.A. Maas Geesteranus (Leiden) for suggestions regarding some taxonomical problems.

\section{References}

Ahti, T., Hämet-Ahti, L. \& Jalas, J. 1968: Vegetation zones and their sections in northeastern Europe. Ann. Bot. Fennici 5: 169-211.

Anonymous 1986: Uhanalaisten eläinten ja kasvien suojelutoimikunnan mietintö 3. Suomen uhanalaiset kasvit. Ympäristöministeriö, komiteamietintö 1985(43): 1-431. Helsinki.

Banker, H. 1913: Type studies in the Hydnaceae 6. The genera Creolophus, Echinodontium, Gloiodon, and Hydnodon. - Mycologia 5: 293-298.

Bendiksen, E. (ed.) 1986: VII Nordic Mycological Congress 1984, Nymoen. List of species observed. - $41 \mathrm{pp}$. Oslo.

Bernicchia, A. \& Caroti, V. 1983: Aphyllophorales in alcuni boschi del litorale toscano. - Quad. Mus. Storia Natur. Livorno 4: 33-44.

Berry, F. \& Lombard, F. 1978: Basidiomycetes associated with decay of living oak trees. - USDA Forest Service Res. Pap. NE-413: 1-8.

Blytt, A. 1905: Norges hymenomyceter. - Vidensk. Selsk Skr. 1 (Math.-naturv. Kl. 6): 1-164.

Bourdot, H. \& Galzin, A. 1927: Hyménomycètes de France. -761 pp. Sceaux.

Breitenbach, J. \& Kränzlin, F. 1986: Fungi of Switzerland 2, Heterobasidiomycetes, Aphyllophorales, Gasteromycetes. - 412 pp. Luzern.

Capellano, A. \& Keller, J. 1978: Architecture de la paroi sporique des Auriscalpiacées et des Hériciacées. Persoonia 9: 511-514.

Coker, W. \& Beers, A. 1951: The stipitate Hydnums of the eastern United States. - 211 pp. Chapel Hill.

Courfenay, B. \& Burdsall, H. 1982: A field guide to mushrooms and their relatives. - 144 pp. New York etc. 
Dahl, E., Elven, R., Moen, A. \& Skogen, A. 1986: Vegetasjonsregionkart over Norge 1: 1500 000. - Nasjonalatlas for Norge, map sheet no. 4.1.1. Statens Kartverk. Oslo.

Domański, S. 1975: Mala flora grzybów 1. Basidiomycetes (podstawczaki), Aphyllophorales (bezblaszkowe) 2: Auriscalpiaceae etc. - 318 pp. Warszawa \& Kraków.

- 1981: Grzyby (Mycota) 13. Podstawczaki, bezblaszkowe, kolczakowate, ząbkowcowate. - 93 pp. Warszawa \& Kraków.

Donk, M. 1962: Notes on resupinate Hymenomycetes 6. Persoonia 2: 217-238.

- 1964: A conspectus of the families of the Aphyllophorales. - Persoonia 3: 199-324.

Eckblad, F.-E. \& Gulden, G. 1974: Distribution of some macromycetes in Norway. - Norwegian J. Bot. 21: 285-301.

Egeland, J. 1911: Meddelser om norske hymenomyceter 1. - Nyt Mag. Naturv. 49: 341-380.

- 1913: Meddelser om norske hymenomyceter 2. - Nyt Mag. Naturv. 51: 53-93.

Eriksson, J. et al. 1973: The Corticiaceae of North Europe 2. Aleurodiscus to Confertobasidium. - Pp. 57-261. Oslo.

- 1975: The Corticiaceae of North Europe 3. Coronicium to Hyphoderma. - Pp. 285-546. Oslo.

- 1976: The Corticiaceae of North Europe 4. Hyphodermella to Mycoacia. - Pp. 547-886. Oslo.

- 1978: The Corticiaceae of North Europe 5. Mycoaciella to Phanerochaete. - Pp. 887-1047. Oslo.

- 1981: The Corticiaceae of North Europe 6. Phlebia to Sarcodontia. - Pp. 1049-1276. Oslo.

- 1984: The Corticiaceae of North Europe 7. Schizopora to Suillosporium. - Pp. 1278-1449. Oslo.

Erkkilä, R. \& Niemelä, T. 1986: Polypores in the parks and forests of the City of Helsinki. - Karstenia 26: 1-40.

Fries, E. 1821: Systema mycologicum 1. - 520 pp. Lundae.

Gilbertson, R. 1963: Resupinate hydnaceous fungi of North America 1. Type studies of species described by Peck. Mycologia 54: 658-677.

Gilbertson, R. \& Ryvarden, L. 1986: North American polypores 1. Abortiporus to Lindtneria. - $433 \mathrm{pp}$. Oslo.

Ginns, J. 1984: Hericium coralloides N. Amer. auct. (= H. americanum sp. nov.) and the European $\mathrm{H}$. alpestre and $\mathrm{H}$. coralloides. - Mycotaxon 20: 39-43.

- 1985: Hericium in North America: cultural characteristics and mating behavior. - Canad. J. Bot. 63: 1551-1563.

- 1986: The genus Dentipellis (Hericiaceae). - Windahlia 16: $35-45$.

Gordienko, P. 1979: Vlianie sostoania substrata na rasselenie derevorazrusayusih gribov. - Mikol. Fitopatol. 13: 421-428.

Gulden, G. \& Stordal, J. 1973: Om stilkete och kjukeformete piggsopper i Norge. - Blyttia 31: 103-127.

Hallenberg, N. 1983: Hericium coralloides and $\mathrm{H}$. alpestre (Basidiomycetes) in Europe. - Mycotaxon 18: 181-189.

Harrison, K. 1973a: The genus Hericium in North America. - Michigan Botanist 12: 177-194.

- 1973b: Aphyllophorales 3, Hydnaceae and Echinodontiaceae. - In: Ainsworth, G., Sparrow, F. \& Sussman, A. (eds.), The fungi, an advanced treatise 4B. A taxonomic review with keys: Basidiomycetes and lower fungi: 369395. New York \& London.

- 1984: Creolophus in North America. - Mycologia 76: 1121-1123.
Hjortstam, K. \& Ryvarden, L. 1984: Some new and noteworthy Basidiomycetes (Aphyllophorales) from Nepal. - Mycotaxon 20: 133-151.

Høgholen, E. \& Ryvarden, L. 1977: Noen nye sopper for Norge. - Blyttia 35: 15-17.

Holmgren, P., Keuken, W. \& Schofield, E. 1981: Index herbariorum 1. The herbaria of the world. 7th ed. Regnum Vegetabile 106: 1-452.

Hultén, E. 1971: Atlas över växternas utbredning i Norden. 2nd ed. -531 pp. Stockholm.

Imazeki, R. \& Hongo, T. 1971: Coloured illustrations of fungi of Japan 1. - $181 \mathrm{pp}$. Osaka.

- 1972: Coloured ilustrations of fungi of Japan 2. $-238 \mathrm{pp}$. Osaka.

Ingelög, T., Thor, G. \& Gustafsson, L. 1984: Floravård i skogsbruket $2 .-408 \mathrm{pp}$. Uddevalla.

Jahn, H. 1965: Die Stachelbärte (Hericium, Creolophus) und ihr Vorkommen in Westfalen. - Westfälische Pilzbriefe 5: $90-100$

- 1969: Einige resupinate und halbresupinate Stachelpilze in Deutschland. - Westfälische Pilzbriefe 7: 113-144.

- 1979: Pilze die an Holz wachsen. - 268 pp. Herford.

Jahn, H. \& Sturm, C. 1983: Der seltene Stachelpilz Gloiodon strigosus ( $\mathrm{Sw}$. ex Fr.) P. Karst. in den Alpen gefunden. - Westfälische Pilzbriefe 10-11: 209-220.

Järva, L. \& Parmasto, E. 1980: Eesti seente koondnimestik. - 331 pp. Tartu.

Jülich, W. 1981: Higher taxa of Basidiomycetes. - Bibliotheca Mycologica 85: 1-485. Vaduz.

- 1984: Die Nichtblätterpilze, Gallertpilze und Bauchpilze (Aphyllophorales, Heterobasidiomycetes, Gasteromycetes). - In: Gams, H. (ed.), Kleine Kryptogamenflora 2b(1), Basidiomyceten 1.626 pp. Stuttgart \& New York.

Jülich, W. \& Stalpers, J. 1980: The resupinate nonporoid Aphyllophorales of the temperate northern hemisphere. - Ver. Kon. Nederl. Akad. Wetensch. Afd. Natuurk. Tweede Reeks 74: 1-335. Amsterdam.

Keller, J. 1976: Ultrastructure des parois sporiques des Aphyllophorales 2. Hericium coralloides. - Schweiz. Z. Pilzkunde 54: 153-159.

- 1986: Ultrastructure des parois sporiques de quelques Aphyllophorales. - Mycol. Helvetica 2: 1-34.

Klán, J. \& Kotilová-Kubiłková, L. 1982: Macrofungi from the West Caucasus 1. Aphyllophoroaceous fungi (Aphyllophorales, Basidiomycetes). - Ceská Mykologie 36: $20-39$.

Knudsen, H. \& Pedersen, H. 1984: De danske koralpigsvampe. - Svampe 10: 91-99.

Korf, R. 1982: Citation of authors' names and the typification of names of fungal taxa published between 1753 and 1832 under the changes in the Code of Nomenclature enacted in 1981. - Mycologia 74: 250-255.

Koski, S. 1983: Puissa kasvavista orakkaista Suomessa. Unpubl. Cand. Phil, thesis, Dept. of Botany, Univ. of Helsinki. 63 pp. Helsinki.

Koski-Kotiranta, S. \& Niemelä, T. 1983: Puitten orakkaat. - Sienilehti 35: 99-116.

Kotlaba, F. \& Pouzar, Z. 1972: Taxonomic and nomenclatural notes on some macromycetes. - Ceská Mykologie 26: 217-222.

Kreisel, H. 1961: Die phytopathogenen Grosspilze Deutschlands. -284 pp. Jena.

- (ed.) 1987: Pilzflora der Deutschen Demokratischen Republik. Basidiomycetes (Gallert-, Hut- und Bauchpilze). $281 \mathrm{pp}$. Jena.

Kreisel, H., Dörfelt, H. \& Benkert, D. 1980: Karten 
zur Pflanzenverbreitung in der DDR 3. Ausgewählte Makromyzeten. - Hercynia 17: 233-291.

Lange, L. 1974: The distribution of macromycetes in Europe. - Dansk Bot. Arkiv 30(1): 1-105.

Lincoff, G. 1981: The Audubon Society field guide to North American mushrooms. - $926 \mathrm{pp}$. New York.

Lind, J. 1913: Danish fungi as represented in the herbarium of E. Rostrup. - 553 pp. København.

Lindsey, J. \& Gilbertson, R. 1978: Basidiomycetes that decay aspen in North America. - 406 pp. Vaduz.

Lyubarskij, L. \& Vasilyeva, L. 1975: Derevorazrusayuscie griby Dal'nego Vostoka. - 164 pp. Novosibirsk.

Maas Geesteranus, R. 1959: The stipitate hydnums of the Netherlands 4. Auriscalpium S.F. Gray, Hericium Pers. ex S.F. Gray, Hydnum L. ex Fr., and Sistotrema Fr. em Donk. - Persoonia 1: 115-147.

- 1962: Hyphal structures in Hydnums. - Persoonia 2: 377-405.

- 1963: Hyphal structures in Hydnums 2-4. - Proc. Kon. Nederl. Akad. Wetensch. (Ser. C) 66: 426-457.

- 1971: Hydnaceous fungi of the eastern Old World. - Verh. Kon. Nederl. Akad. Wetensch., Afd. Natuurk. (Sect. 2) 60: $1-176$.

- 1974: Studies in the genera Irpex and Steccherinum. Persoonia 7: 443-581.

- 1976a: Notes on Hydnums 10. - Proc. Kon. Nederl. Akad. Wetensch. (Ser. C) 79: 273-289.

- 1976b: Reflections upon Clavicorona dryophila. - Proc. Kon. Nederl. Akad. Wetensch. (Ser. C) 79: 147-149.

- 1978: Notes on Hydnums 11. - Persoonia 9: 491-500.

Marchand, A. 1976: Champignons du Nord et du Midi 4. Aphyllophorales (fin), Hydnaceae, Gasteromycetes \& Ascomycetes. - $361 \mathrm{pp}$. Perpignan.

Melik-Hacatryan, D. \& Martirosyan, S. 1971: Gasteromicety i afilloforovye griby. - In: TeterevnikovaBabayan, D. (ed.), Mikoflora Armyanskoj SSR 2. 383 pp. Erevan.

Miller, L. \& Boyle, J. 1943: The Hydnaceae of Iowa. Iowa Univ. Stud. Nat. Hist. 18: 1-92.

Miller, O. \& Stewart, L. 1971: The genus Lentinellus. - Mycologia 63: 333-369.

Neubert, H. 1969: Dentipellis fragilis (Pers. ex Fr.) Donk, ein resupinater Stachelbart. - Westfälische Pilzbriefe 7 : 105-107.

Niemelä, T. 1985a: On Fennoscandian polypores 9. Gelatoporia n. gen. and Tyromyces canadensis, plus notes on Skeletocutis and Antrodia. - Karstenia 25: 21-40.

- 1985b: Mycoflora of Poste-de-la-Baleine, northern Québec. Polypores and the Hymenochaetales. - Naturaliste Canadien 112: 445-472.

Niemelä, T. \& Saarenoksa, R. 1985: Dentipellis fragilis and Steccherinum oreophilum: Finnish records on hydnaceous fungi. - Karstenia 25: 70-74.

Nikolaeva, T. 1961: Ežovikovye griby. - In: Savǐ̌, V. (ed.), Flora sprovyh rastenij SSSR 6 (griby 2). 443 pp. Moskva \& Leningrad.

Nuss, I. 1973: Über die Verbreitung des Alpen-Stachelbartes (Hericium coralloides) in der Bundesrepublik Deutschland. - Westfälische Pilzbriefe 9: 130-134.

Persoon, C. 1825: Mycologia europaea 2. - 214 pp. Erlangae.

Phillips, R. 1981: Mushrooms and other fungi of Great Britain and Europe. $-288 \mathrm{pp}$. London.

Plank, S. 1978: Ökologie und Verbreitung holzabbauender Pilze im Burgenland. - Wiss. Arb. Burgenland 61: 1207.
Pomerleau, R. 1980: Flore des champignons au Québec et régions limitrophes. $-652 \mathrm{pp}$. Montréal.

Rattan, S. 1977: The resupinate Aphyllophorales of the North Western Himalayas. - Bibliotheca Mycologica 60: 1-427. Vaduz.

Reid, D. 1963: New or interesting records of Australasian Basidiomycetes 5. - Kew Bull. 17: 267-308.

Ryman, S. \& Holmåsen, I. 1984: Svampar, en fälthandbok. -718 pp. Stockholm.

Ryvarden, L. 1971: Studies in the Aphyllophorales of Finnmark, northern Norway. - Rep. Kevo Subarctic Res. Sta. 8: $148-154$.

Scopoli, G. 1772: Flora carniolica. 2nd ed. - 496 pp. Vindobonae.

Schmid-Heckel, H. 1985: Zur Kenntnis der Pilze in den Nördlichen Kalkalpen. - Nationalpark Berchtesgaden Forsch. Ber. 8: 1-201.

Stafleu, F. \& Cowan, R. 1985: Taxonomic literature 5: Sal-Ste. 2nd ed. - Regnum Vegetabile 112: 1-1066. Utrecht \& Antwerpen.

Stalpers, J. 1978: Identification of wood-inhabiting Aphyllophorales in pure culture. - Stud. Mycology (Centraalbureau voor Schimmelcultures, Baam) 16: 1-248.

Strid, A. 1975: Wood-inhabiting fungi of alder forests in North-Central Scandinavia 1. Aphyllophorales (Basidiomycetes). Taxonomy, ecology and distribution. - Wahlenbergia 1: 1-237.

- 1982: Svenska taggsvampar 1-2. Historik, definition och systematik. - Jordstjärnan 3: 14-21.

- 1983a: Svenska taggsvampar 3. Vedväxande arter. - Jordstjärnan 4: 16-28.

- 1983b: Svenska taggsvampar 4. Släktena Auriscalpium, Bankera, Phellodon, Sistotrema och Hydnum. - Jordstjärnan 4: 10-14.

Sunhede, S. 1977: Något om ved- och barkbeboende eksvampar i Sverige. - Svensk Bot. Tidskr. 71: 101-108.

Svarcman, S. 1964: Geterobazidial'nye i avtobazidial'nye griby. - In: Flora Spor. Rast. Kazahstana 4. 716 pp. Alma-Ata.

Swartz, O. 1810: Svamparter, saknade i Fl. Svec. L., fundne i Sverige och beskrifne af Olof Swartz 3. - Kongl. Vetenskaps Acad. Nya Handl. 31 (3: October, November, December): 237-252.

Tellería, M. 1980: Contribución al estudio de los Aphyllophorales espanioles. - Bibliotheca Mycologica 74: 1-464. Vaduz.

Tortić, M. \& Jelić, M. 1977: The family Hericiaceae and the genus Climacodon in Yugoslavia. - Acta Bot. Croatica 36: 153-164.

Winge, Ø. 1945: Notiser. Hydnum septentrionale Fr. Friesia 3: 147-148.

Wojewoda, W. 1973: Climacodon septentrionalis (Fr.) P. Karst. w Polsce. - Fragm. Flor. Geobot. 19: 129-133.

Wojewoda, W. \& Ławrynowicz, M. 1986: Czerwona lista grzybów wielkoowocnikowych zagrożonych w Polsce. Red list of threatened macrofungi in Poland. - In: Lista roślin wymierających i zagrożonych w Polsce 3: 47-82.

Zerova, M., Radzievskij, G. \& Ševčenko, S. 1972: Viznacnik gribiv Ukrajni 5, Bazidiomiceti 1, ekzobazidial'ni, afiloforal'ni, kantarelal'ni. -240 pp. Kijv.

Accepted for publication

on 14 March 1987 